$\mathbb{1}$ ) Nordic Council of Ministers

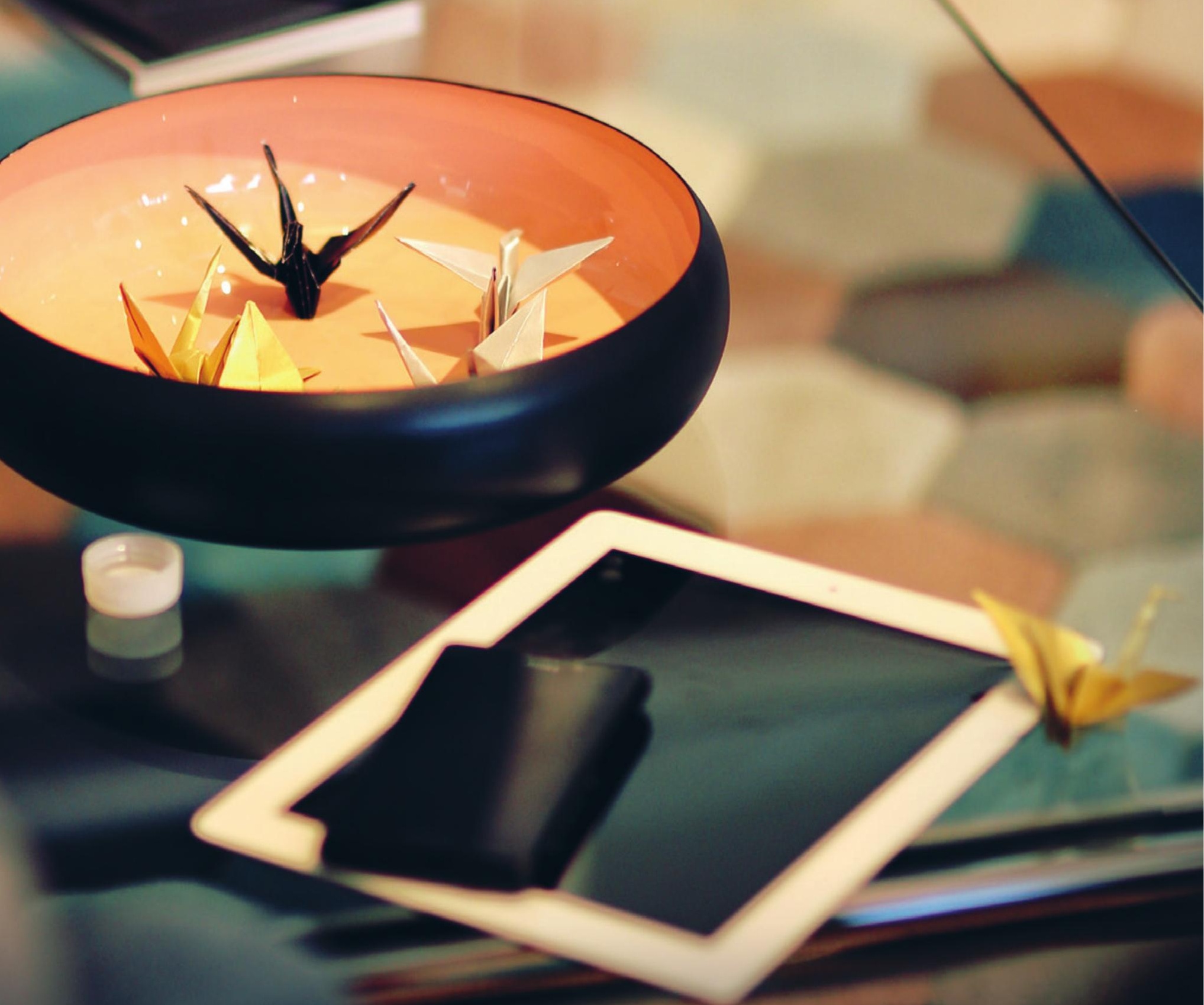

\title{
CIRCULAR ECONOMY AND THE NORDIC SWAN ECOLABEL
}

An Analysis of Circularity in the Product-Group-Specific Environmental Criteria 



\section{Circular Economy and the Nordic Swan Ecolabel}

An Analysis of Circularity in the Product-Group-Specific Environmental Criteria

Suikkanen, Johanna and Nissinen, Ari

TemaNord 2017:553 


\section{Circular Economy and the Nordic Swan Ecolabel}

An Analysis of Circularity in the Product-Group-Specific Environmental Criteria

Suikkanen, Johanna and Nissinen, Ari

ISBN 978-92-893-5153-9 (PRINT)

ISBN 978-92-893-5154-6 (PDF)

ISBN 978-92-893-5155-3 (EPUB)

http://dx.doi.org/10.6027/TN2017-553

TemaNord 2017:553

ISSN 0908-6692

Standard: PDF/UA-1

ISO 14289-1

(c) Nordic Council of Ministers 2017

Cover photo: unsplash.com

Print: Rosendahls

Printed in Denmark

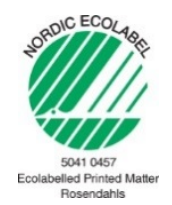

Disclaimer

This publication was funded by the Nordic Council of Ministers. However, the content does not necessarily reflect the Nordic Council of Ministers' views, opinions, attitudes or recommendations.

Rights and permissions

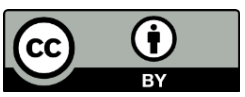

This work is made available under the Creative Commons Attribution 4.0 International license (CC BY 4.0) https://creativecommons.org/licenses/by/4.o.

Translations: If you translate this work, please include the following disclaimer: This translation was not produced by the Nordic Council of Ministers and should not be construed as official. The Nordic Council of Ministers cannot be held responsible for the translation or any errors in it.

Adaptations: If you adapt this work, please include the following disclaimer along with the attribution: This is an adaptation of an original work by the Nordic Council of Ministers. Responsibility for the views and opinions expressed in the adaptation rests solely with its author(s). The views and opinions in this adaptation have not been approved by the Nordic Council of Ministers. 
Third-party content: The Nordic Council of Ministers does not necessarily own every single part of this work. The Nordic Council of Ministers cannot, therefore, guarantee that the reuse of third-party content does not infringe the copyright of the third party. If you wish to reuse any third-party content, you bear the risks associated with any such rights violations. You are responsible for determining whether there is a need to obtain permission for the use of third-party content, and if so, for obtaining the relevant permission from the copyright holder. Examples of third-party content may include, but are not limited to, tables, figures or images.

Photo rights (further permission required for reuse):

Any queries regarding rights and licences should be addressed to:

Nordic Council of Ministers/Publication Unit

Ved Stranden 18

DK-1061 Copenhagen K

Denmark

Phone +4533960200

pub@norden.org

\section{Nordic co-operation}

Nordic co-operation is one of the world's most extensive forms of regional collaboration, involving Denmark, Finland, Iceland, Norway, Sweden, and the Faroe Islands, Greenland and Åland.

Nordic co-operation has firm traditions in politics, economics and culture and plays an important role in European and international forums. The Nordic community strives for a strong Nordic Region in a strong Europe.

Nordic co-operation promotes regional interests and values in a global world. The values shared by the Nordic countries help make the region one of the most innovative and competitive in the world.

The Nordic Council of Ministers

Ved Stranden 18

DK-1061 Copenhagen K, Denmark

Tel.: +453396 o200 www.norden.org

Download Nordic publications at www.norden.org/nordpub 


\section{Contents}

Definitions .7

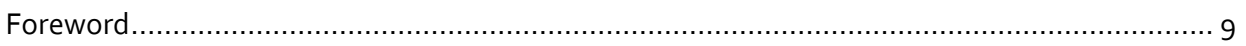

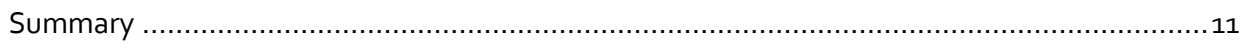

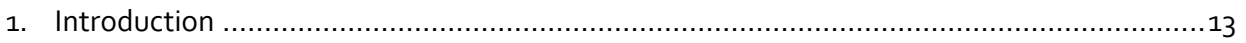

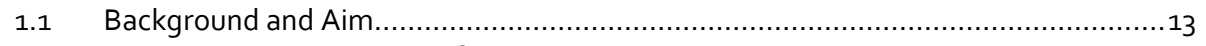

1.2 Nordic Swan Ecolabelling of Goods and Services ...............................................14

1.3 Circular Economy and Product Circularity .................................................. 16

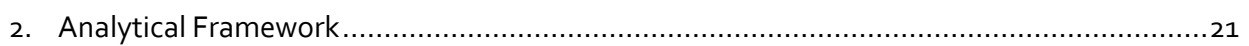

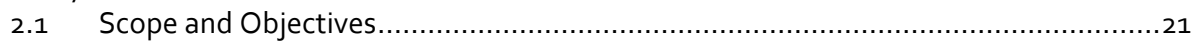

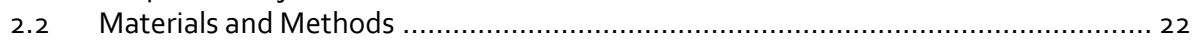

3. Results: Circular Economy aspects in the Swan Criteria for Goods ................................ 25

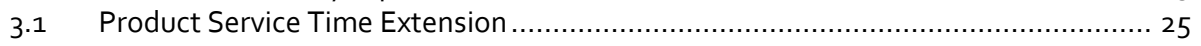

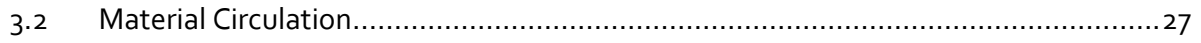

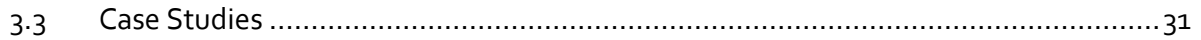

4. Swan and Innovative Forms of Consumption and Production ..................................... 41

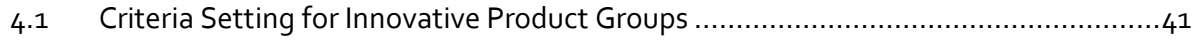

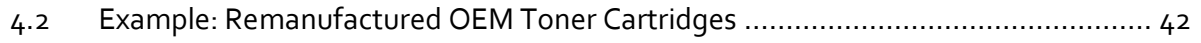

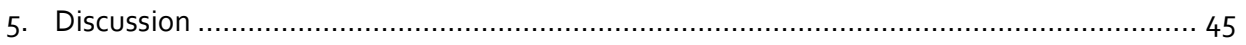

5.1 Circularity in Swan Ecolabel Criteria .............................................................. 45

5.2 Addressing Innovative Product Groups...................................................... 46

5.3 Role of the Nordic Swan Ecolabelling in Circular Economy ..................................... 47

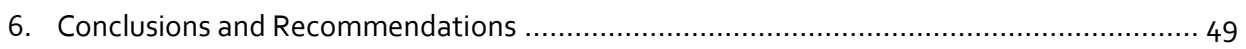

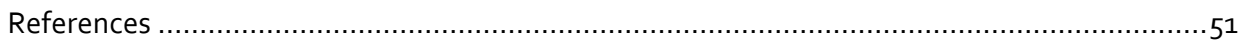

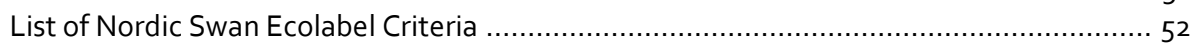

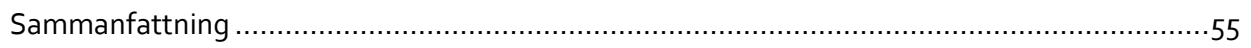





\section{Definitions}

- By-product Utilisation: A substance or object, resulting from a production process, the primary aim of which is not the production of that item, may be regarded as not being waste, but as being a by-product, when its use is certain and does not require further processing other than normal industrial practice. ${ }^{1}$

- Circular Economy: An economy where the value of products, materials and resources is maintained in the economy for as long as possible and the generation of waste is minimised. ${ }^{2}$

- Criteria Documents: Specify the requirements that a company must meet to obtain an ecolabel. ${ }^{3}$

- Durability: Product characteristic that determines the length of time over which it maintains its value or functionality. ${ }^{4}$ Here, durable products refer to longerlasting, resisting products.

- Ecolabel: An environmental label indicating overall environmental preferability of a product within a particular product category. ${ }^{5}$

- Life Cycle: Consecutive and interlinked stages of a product system, from raw material acquisition or generation from natural resources to final disposal. ${ }^{6}$

- Life Cycle Assessment: Compilation and evaluation of the inputs, outputs and the potential environmental impacts of a product system throughout its life cycle. ${ }^{7}$

- Material Circularity: A description (or measure) of how restorative or linear the flow of the materials for the product is and how long and intensely the product is used. ${ }^{8}$

- Multi-functionality: Product features by which the product serves several use purposes. ${ }^{9}$

- New Criteria: In a Nordic Swan Ecolabel criteria document specifies the areas of development for the forthcoming revisions of the criteria.

- Non-toxic Material Cycles: The limiting and risk management of chemicals hazardous to health and the environment in recycling and uptake of secondary raw materials. ${ }^{10}$

\footnotetext{
${ }^{1} \mathrm{EC}(2008)$.

2 EC (2015), p.2.

3 Nordic Swan Ecolabel Criteria Documents: http://www.nordic-ecolabel.org/criteria/

4 WBCSD (2017).

${ }^{5}$ Adapted from definition of Type 1 Environmental Labelling Programme of ISO 14024: 1999.

${ }^{6}$ Environmental Management. Life Cycle Assessment. Requirements and Guidelines - SFS-EN ISO 14044:2006.

7 Environmental Management. Life Cycle Assessment. Requirements and Guidelines - SFS-EN ISO 14044:2006.

${ }^{8}$ Ellen MacArthur Foundation (2015a), p.16

9 Mäkivuokko (2001), p. 25.

${ }^{10}$ Adapted from EC (2015), p. 12.
} 
- Potential: In the Nordic Swan criteria setting process, the potential of gaining environmental benefits of Swan-labelled product groups or services. ${ }^{11}$

- Product Life Time Extension: Product characteristics that lengthen the time over which that product continues to serve its originally intended function. ${ }^{12}$

- Product Service Time Extension: Used in this report to denote product life time extension and intensified use of a product.

- Recycling: Any recovery operation by which waste materials are reprocessed into products, materials or substances, whether for the original or other purposes, including reprocessing of organic waste but excluding energy recovery. ${ }^{13}$

- Recyclability: Product characteristics that make recycling possible, e.g. quality of material and ease of disassembly. ${ }^{14}$

- Remanufacturing: A series of manufacturing steps acting on an end-of-life part or product in order to return it to like-new or better performance with corresponding warranty. ${ }^{15}$

- Reuse: Any operation by which products or components that are not waste are used again for the same purpose for which they were conceived. ${ }^{16}$

- Reparability: Product design that allows repair for maintaining the product function, including easy access to parts, fault diagnostics, part inter-changeability, identification of components and leads as well as information on repair. ${ }^{17}$

- RPS: "Relevance", "Potential", "Steerability".

- Relevance: In the Nordic Swan criteria setting process, an assessment of what environmental problems exists in the product group and how large the problems are. ${ }^{18}$

- Secondary Raw Materials: Recycled raw materials that are injected back into the economy as new raw materials, replacing traditional extractive resources. ${ }^{19}$

- Steerability: In the Nordic Swan criteria setting process, the potential of the Nordic Swan Ecolabel to address an environmental problem. ${ }^{20}$

- Upgradability: The maintaining or improving of product function through renewing a product or component. ${ }^{21}$ It is different from upcycling, which denotes a process of converting materials into new materials of increased functionality or higher quality or value. ${ }^{22}$

\footnotetext{
${ }^{11}$ Nordic Swan Ecolabel (2013a).

${ }^{12}$ WBCSD (2017).

${ }_{13}$ Directive 2008/98/EC, p. 10

${ }^{14}$ Adapted from Mäkivuokko (2001) p. 25.

15 EC (2015), p.5.

${ }^{16}$ Directive 2008/98/EC, p. 10.

${ }^{17}$ Circular Economy Toolkit and Seppälä et al. (2016), p.39.

${ }^{18}$ Nordic Swan Ecolabel (2013a).

19 EC (2015), p.11.

${ }^{20}$ Nordic Swan Ecolabel (2013a).

${ }^{21}$ Mäkivuokko (2001), p.25.

22 Ellen MacArthur Foundation (2015a), p.17 and Seppälä et al. (2016), p.25
} 


\section{Foreword}

Transitioning to a resource-efficient circular economy will require actively sought improvements in the way products are designed, produced and consumed. Private and public purchasers are seen as having an important role in driving change through market pressure. However, this necessitates consumer information and guidance as well as products with better environmental performance. Also, options for more efficient consumption modes will need to be available.

The Nordic Swan Ecolabel is an established Type I ecolabel that is widely known and valued by consumers in the Nordic countries. It is, therefore, important to understand the role that the Nordic scheme plays in steering consumption modes and product design towards circular economy and how the influence could be further strengthened.

This report was prepared as part of the project "Nordic Swan, Circular Economy and Product Environmental Footprint" funded by the Nordic Council of Ministers, within the scope of the projects under the Finnish Presidency in 2016. The project explores how the product-specific award criteria of the Nordic Swan promote circular economy and how they could be further strengthened in terms of, e.g., product durability, and circulation of material. The project further studies the Product Environmental Footprint (PEF) methodology, currently being developed by the European Commission, and how the information provided by the life cycle assessment-based methodology could be used by the Swan.

In this report, we present our analysis of the ways in which circular economy aspects are included in the Swan label award criteria, explore the role the Swan can have in promoting innovative ways of consumption and production, and discuss the role that the Nordic Swan can have in steering products in a circular economy direction in the future. We would like to acknowledge Karin Bergbom and Elisabeth Magnus from Nordic Swan Ecolabelling for their comments and feedback that helped shape this report. 



\section{Summary}

The term "Circular Economy" has emerged in recent years as a way to denote an economy where natural resources are efficiently used and where their value is kept in the economy as long as possible. Its focus is on two inherent attributes: service life of products and material circulation. The transformation necessitates that citizens and authorities have the right incentives for choosing products and services with lower environmental impacts, in the form of suitable price signals and sufficient environmental information. An ecolabel indicates that the product is, environmentally speaking, among the best products available on the market. The Nordic Swan Ecolabel has been designed so as to steer stepwise developments towards sustainability. For this report, the product-group-specific award criteria documents were analysed with the objective to identify requirements that promote circular economy through product service time extension and material circulation.

The Swan criteria promote good quality products with requirements on durability, warranties and availability of replacement parts as requirements. The use of secondary raw materials as material input for products and packaging can be noted. Separability (or the possibility to separate materials) is already seen in the criteria for some product groups and is expected to gain strengthened attention in the future, as indicated by the "New Criteria" chapters. Recyclability is, in addition to separability, helped or hindered by the material content. One important aspect noted in the analysis is the presence of hazardous chemicals, which may hinder recycling. Such chemicals are limited by ecolabel requirements.

This report was prepared as part of a Nordic project, and the results could be useful in the development of the Nordic Swan Ecolabel in the future. Future criteria development might more closely focus on aspects including upgradability, reparability and multi-functionality, as well as component reuse. Secondly, it is recommended that the role of the Swan in promoting innovative forms of consumption and production in the scope of circular economy is assessed, and an assessment of the associated process for establishing criteria is made. The Nordic Swan Ecolabel is a central tool that can steer consumer and producer choices through a market-based approach. 



\section{Introduction}

\subsection{Background and Aim}

According to the Roadmap to a Resource Efficient Europe, today, in the European Union, each person consumes 16 tonnes of materials annually, of which 6 tonnes are wasted, with half going to landfills. ${ }^{23}$ Consequent environmental impacts, including overuse of natural resources, climate change and chemicalisation of the environment make current consumption patterns unsustainable. A systemic transformation of the economy, favouring sustainable management of environmental resources, reuse, recycling and substitution of materials, was proposed by the European Union's Roadmap to a Resource Efficient Europe (COM (2011) 517 final) and has been further developed in the Circular Economy Action Plan (COM(2015) 614 final). These efforts aim towards decoupling growth from the use of natural resources in line with United Nations Sustainable Development Goal \#12, which also calls for action in achieving sustainable management of natural resources and reduction in waste generation by $2030 .{ }^{24}$

Amongst various other proposals, the Roadmap to a Resource Efficient Europe draws attention to the role of consumers by establishing that by 2020 citizens and authorities have the right incentives to choose the most resource-efficient products and services in the form of suitable price signals and sufficient environmental information. ${ }^{25}$ Also, the Nordic Council of Ministers' (NCM) Environmental Action Plan (MHP) 2013 2018 underlines environmental information as an important tool in the move towards sustainable consumption, notwithstanding better coordination of tools and instruments for environmental information, as well as further development of environmental declarations. ${ }^{26}$

This research was conducted as a part of the project entitled "Nordic Swan Ecolabel Swan, Circular Economy and Product Environmental Footprint" funded by the Nordic Council of Ministers (2016-2018). This report aims to analyse how the product-groupspecific criteria of the Nordic Swan Ecolabel (hereinafter "Swan") integrate circularity and to present ideas on how to further develop the criteria so that they contribute towards the circular economy.

\footnotetext{
23 EC (2011), p.2.

24 UN Sustainable Development Goals.

25 EC (2011), p. 5.

${ }^{26}$ Nordic Council of Ministers (2013).
} 


\subsection{Nordic Swan Ecolabelling of Goods and Services}

Product ecolabels guide consumer choices towards product and service options that have a better environmental performance. An ecolabel indicates that the product is, environmentally speaking, among the best - performing products available on the market. It is further expected that the market pressure created by consumer choices encourages producers and service providers to offer environmentally friendlier choices through product development that considers the life cycle environmental impacts of a product. ${ }^{27}$

In the Nordic market, the Swan ecolabel is a central tool for guiding consumer choice, well recognised by consumers. According to market research by the Nordic Swan Ecolabel, $91 \%$ of Nordic consumers recognize the label, and $51 \%$ look for the label when shopping. ${ }^{28}$ It is a "Type I", ecolabel according to ISO14024.

Figure 1: The Nordic Swan Ecolabel

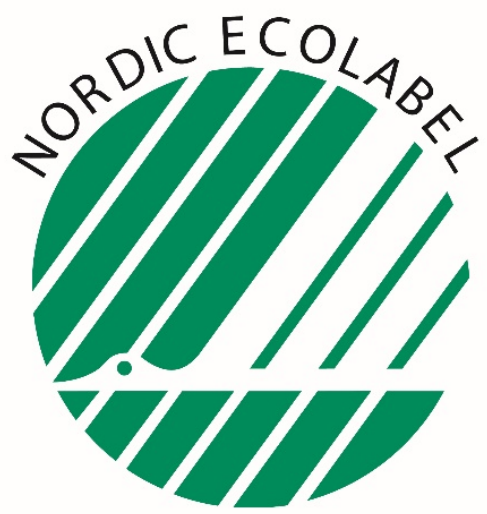

Source: The Nordic Swan Ecolabel.

The focus of the Swan is on the following: (a) Setting strict energy requirements to reduce the climate effect, (b) Minimization of chemical substances that are harmful to health and the environment, (c) Promoting quality products that are resource efficient; and (d) Ensuring biodiversity protection by relying on credible certification schemes. ${ }^{29}$ The Swan also places requirements on function and quality. ${ }^{30}$

The Swan award criteria are developed on the basis of a holistic Life Cycle perspective of the product's impacts, paying attention to avoiding "burden shifts" between a product's different life cycle stages. They are designed so that only the best third of the products on the market receives the label. ${ }^{31}$ The criteria are revised periodically (every $3-5$ years), which creates a stepwise push towards sustainability..$^{32}$

\footnotetext{
${ }^{27}$ Nordic Swan Ecolabel website (Finnish version): http://www.joutsenmerkki.fi

${ }^{28}$ YouGov (2015).

29 Nordic Swan Ecolabel (2011), p.2.

$3^{30}$ Nordic Swan Ecolabel (2014a), p.1.

${ }^{31}$ Nordic Swan Ecolabel (2014a), p.3.

${ }^{32}$ Nordic Swan Ecolabel (2014a), p. 4.
} 


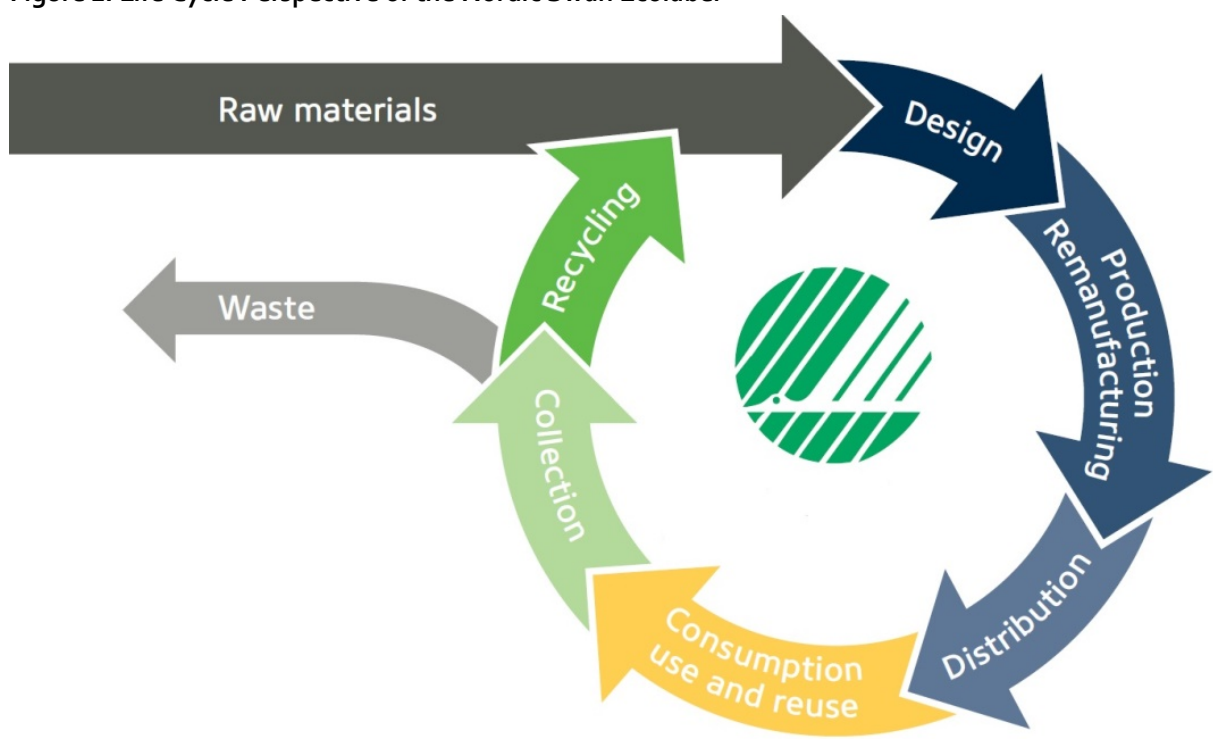

Source: The Nordic Swan Ecolabel (2017a).

Three underlying principles are used in defining the product-specific requirements. These are: Relevance $(R)$, Potential $(P)$, and Steerability (S), where:33

- Relevance identifies the extent of the environmental problem for the product group.

- Potential determines what can be done about the problem.

- Steerability identifies how well the Nordic Swan Ecolabel can influence the problem.

As a first step of the "RPS" process, a "MECO" analysis is performed, where the Raw Materials, Energy, Chemicals and Other environmental aspects relevant to a specific product group from a Life Cycle Perspective are described. The MECO analysis is primarily used to determine the relevance of the environmental impact on the product group and to balance environmental problems. ${ }^{34}$ The analysis is based on a synthesis of information from existing LCAs and other relevant assessments. 35 The assessment of steerability then scopes down the focus of the criteria requirement so that labelling a product will have an influence on improving its performance, taking into consideration relevant impacts of the product's life cycle. It is important to understand the process in order to assess the potential that the ecolabel could have as a tool to steer towards circular economy.

\footnotetext{
33 Nordic Swan Ecolabel (2013a).

34 Nordic Swan Ecolabel (2013a) and Pommer, K. et al. (2001).

35 Nordic Swan Ecolabel (2013b), p.5.
} 


\subsection{Circular Economy and Product Circularity}

The term "Circular Economy" has emerged in recent years as a way to denote an economy where natural resources are efficiently used and where their value is kept in the economy for as long as possible. ${ }^{36}$ Although a relatively new term in policy making, from the perspective of material flows it is a culmination of various different schools of thought. ${ }^{37}$ Its focus is in essence on two inherent attributes: service life of products and material circulation. The following two sections present: (1) the actions proposed to steer Europe towards a Circular Economy, and (2) a way of measuring the circularity of products.

\subsubsection{European Union Action Plan for the Circular Economy}

Closing the Loop - An EU Action Plan for the Circular Economy (COM/2015/0614 final) proposes needed actions at each stage of a product's life cycle and draws attention to boosting the market for secondary raw materials, revised quality standards and a promotion of non-toxic material cycles. ${ }^{38}$ The Action Plan proposes indicators to measure the circular economy at the macro level. The focus is on raw material supply, repair, reuse, waste generation, waste management, secondary raw materials and the use of recycled materials in products. Table 1 Circular Economy Areas of Development lists (nonexhaustive) the topics of actions identified in the Action Plan for each life cycle stage.

\footnotetext{
${ }^{36} \mathrm{EC}$ (2015).

${ }^{37}$ Seppälä et al. (2016), p. 10.

${ }^{38} \mathrm{EC}$ (2015).
} 
Table 1: Circular Economy Areas of Development

$\begin{array}{ll}\text { Life Cycle Stage } & \text { Areas for development } \\ \text { Product Design } & \text { Improve product: } \\ & \text { Durability } \\ & \text { Reparability } \\ \text { Upgradability } & \text { Recyclability } \\ & \text { Also mentioned: remanufacturing, disassembly, recovery of valuable materials } \\ & \text { and components } \\ & \text { Substitution of Chemicals of Concern } \\ & \text { Sustainable sourcing } \\ & \text { By-product reuse } \\ & \text { Remanufacturing } \\ & \text { Innovative industrial processes } \\ & \\ \text { Production Process } & \text { Energy performance } \\ & \text { Durability } \\ & \text { Durability information to consumers } \\ & \text { Reparability } \\ \text { Consumption } & \text { Reuse } \\ & \text { Innovative forms of consumption } \\ & \text { Recycling of packaging } \\ \text { Sorting Schemes } \\ \text { Recovery of materials } \\ \text { Recycling } \\ \text { Recyclability } \\ \text { Promotion of non-toxic cycles } \\ \text { Biodegradable materials } \\ \end{array}$

Source: Adapted from EC (2015).

\subsubsection{Product Circularity Indicators}

A body of analytical work that fed into the European Commission's analysis, as well as broader development and awareness-raising work on circular economy has been led and carried out by the UK-based, non-for-profit Ellen MacArthur Foundation. The Circular Economy model presented by the Foundation differentiates between Biological Cycles and Technical Cycles (Figure 3). In Biological Cycles, non-toxic materials are restored into the biosphere while rebuilding natural capital. 39 In Technical Cycles, products, components and materials are restored into the market at the highest possible quality and for as long as possible, through repair and maintenance, reuse, refurbishment, remanufacture and ultimately recycling.

39 The term "toxic" is understood in this context more broadly to encompass hazardous substances. 


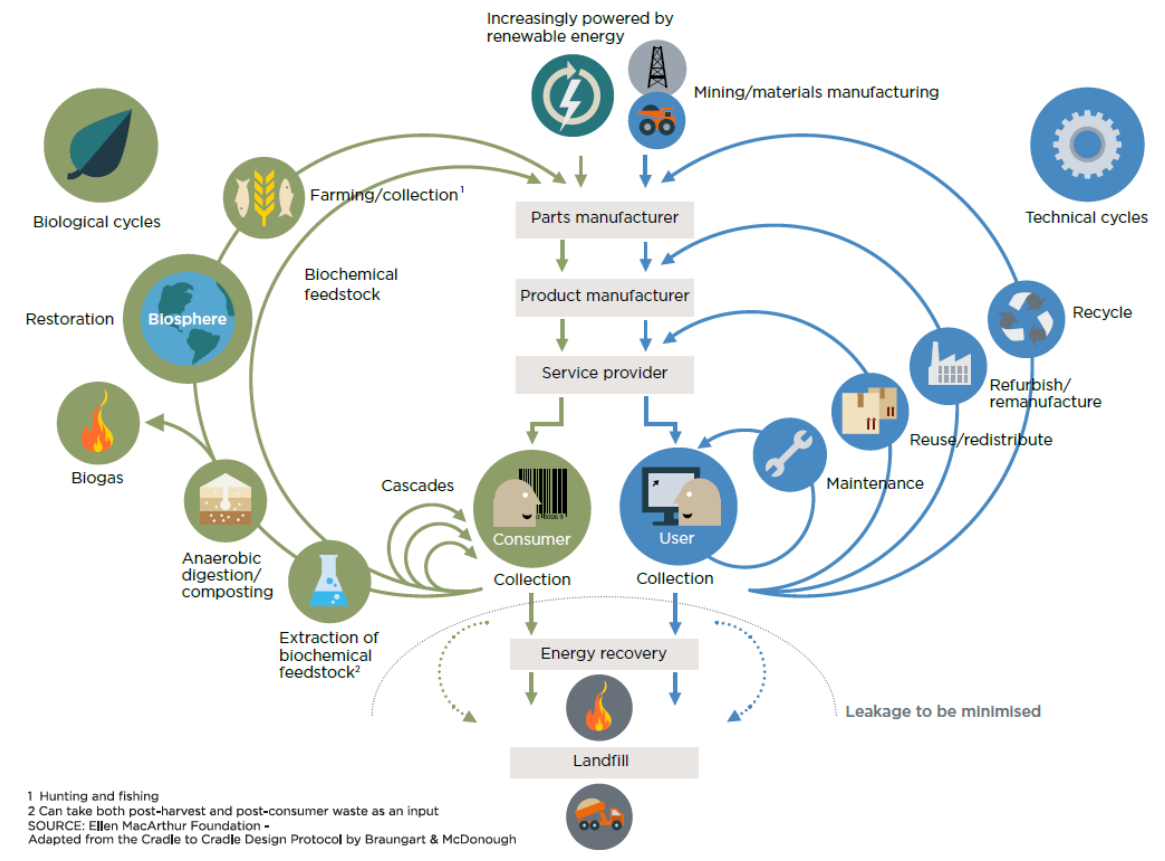

Source: Ellen MacArthur Foundation (2015a), p. 8.

The Circular Economy model of material flows is based on four principles:

1. Using feedstock from reused or recycled sources.

2. Reusing components or recycling materials after the use of the product.

3. Keeping products in use longer.

4. Making more intense use of products..$^{\circ}$

The ways in which these principles are put into practice, with respect to the material flows of the Technical Cycle, are presented in Figure $4^{4{ }^{41}}$

\footnotetext{
40 Ellen MacArthur Foundation (2015a), p.10.

${ }^{41}$ In addition, the indicators take into consideration enabling factors such as efficiency of recycling processes and complementary indicators related to material price variation, REACH/ROHS compliance, Conflict Material Reporting, Energy Usage, $\mathrm{CO}_{2}$ footprint and Water Use. Also, the efficiency of the recycling processes used to produce recycled input and recycle material after use is considered. Ellen MacArthur Foundation (2015a).
} 


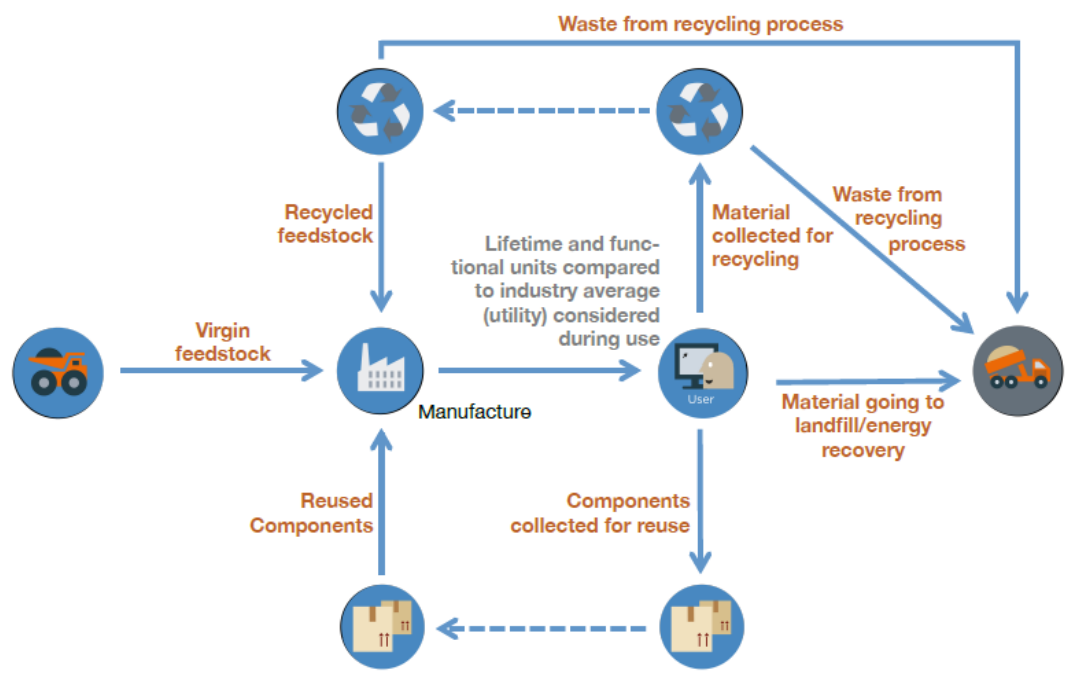

Source: Ellen MacArthur Foundation (2015) Material Circularity Indicators: Methodology, p.19.

The Material Circularity Indicators provides a methodology for measuring how much a product's materials circulate, i.e. how "restorative" material flows are, but excludes an assessment of the material choices or other impacts of the product..$^{42}$ The indicators included in the calculation of the "restorativity" of a product are presented in Table 2.

Table 2: Product Circularity indicators 43

\section{Life Cycle Stage Indicators for Circularity}

Product Design $\quad$ No explicit indicators for product design. The Material Circularity Indicator stemming from each of the life cycle stages can be used to design and redesign products.

Production Process Input from reused feedstock and recycled feedstock, taking into consideration recycling efficiency.

Consumption Product use duration (reuse, redistribution, repair, maintain).

Product use intensity (e.g., shared consumption business models).

End of Life Amount of material collected for recycling.

Amount of material going to landfill and energy recovery.

Amount of materials or components going for reuse.

Source: Adapted from Ellen MacArthur Foundation (2015) Material Circularity Indicators: Methodology.

The indicators have been developed for use in product design decisions, and may also be used for internal reporting, procurement decisions and rating of companies, for example. ${ }^{44}$ In this report, they are also considered as one useful starting point for assessing "product circularity" (or "restorativity") in ecolabelling criteria.

\footnotetext{
42 Ellen MacArthur Foundation (2015a), p.9-10.

43 Adapted from Ellen MacArthur Foundation (2015a).

44 Ellen MacArthur Foundation (2015a), p. 3.
} 



\section{Analytical Framework}

\subsection{Scope and Objectives}

As described in the previous chapters, circular economy focuses on setting requisites on the material use and ensuring that products stay in use for as long as possible. The analytical framework for this study is based on the model presented by the Material Circularity Indicators and complemented by the proposals presented by the EU Action Plan for a Circular Economy, as summarised in the earlier chapter and presented in Figure 5 below.

The review had the objective of answering the following questions:

1. Which Product-Group-Specific Criteria Documents include requirements that promote product service time extension, i.e., are there requirements for: (a) durability, (b) reparability (c) upgradability, and (d) multi-functionality? ${ }^{45}$

2. Which Product-Group-Specific Criteria Documents include requirements that promote the circulation of materials, i.e. are there requirements for (a) input of secondary raw material (recycled feedstock), (b) reuse of components or byproducts, (c) recycling in production and at end-of-life, (d) recyclability and (e) non-toxic material cycles?

The analysis focuses on material circulation in the "technical cycle" given that no indicators for the biological restoration potential were not publicly available at the time of this analysis. The focus of the analysis is on the criteria for goods.

45 This requirement was not found in our literature review, but we consider that it is a factor contributing to the more intense use of a product during its life cycle. 
Figure 5: Analytical Framework - Nordic Swan and Circular Economy

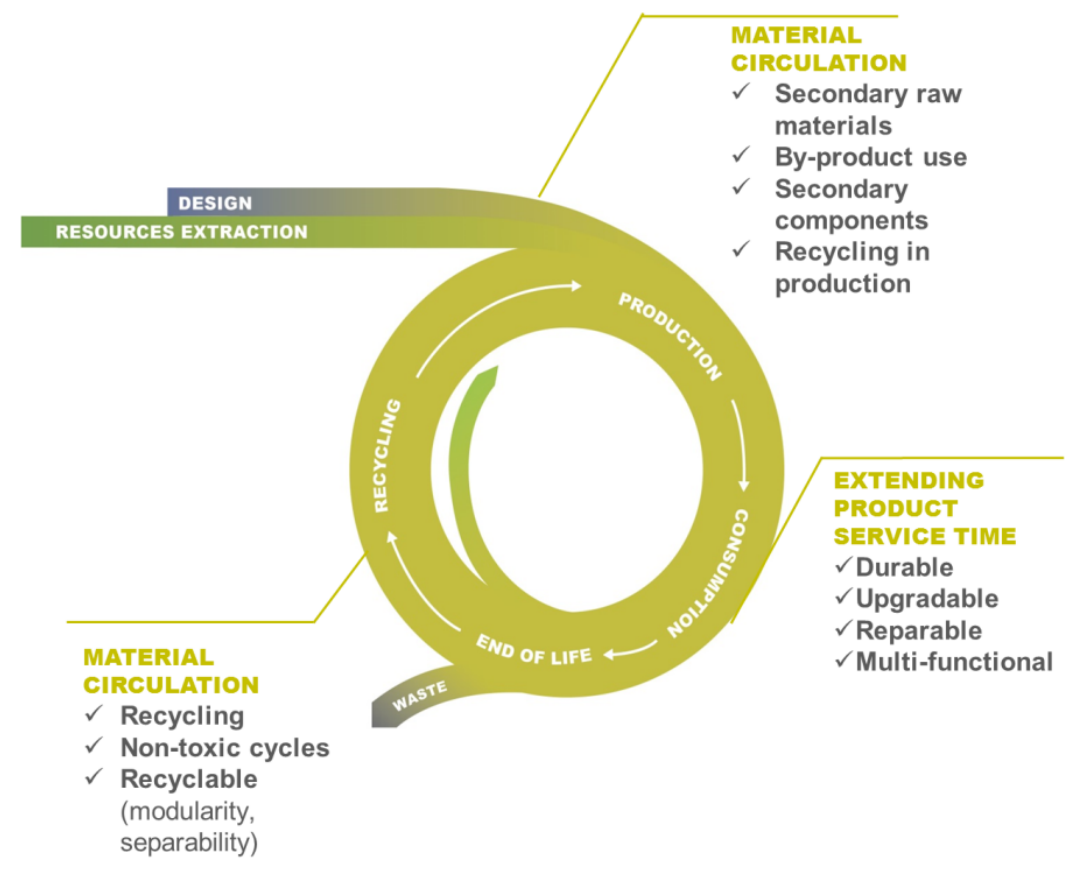

\subsection{Materials and Methods}

The criteria documents were screened for attributes relating to (a) service time extension and (b) material circulation. The materials and methods used to are summarised in Table 3.

Table 3: Overview of Materials and Methods

Materials and Methods overview

Materials

50 Product-group-specific criteria documents for goods, and associated relevant background documents, publicly available and accessed through http://www.joutsenmerkki.fi

Publicly available documents related to the Nordic Swan Ecolabelling Scheme available at www.nordic-ecolabel.org and www.joutsenmerkki.fi

Internal documents of the Nordic Swan Ecolabel provided by the Finnish and Norwegian Ecolabelling organisations.

Methods Desktop study of the documents of the Nordic Swan Ecolabelling scheme

Review of all Product Specific criteria documents using the analytical framework.

Discussions with criteria development experts in the Finnish and Norwegian Ecolabelling organisations. $4^{6}$

$4^{6}$ The chapter about innovative product groups is entirely based on information provided by the Finnish and Norwegian Ecolabelling organisations as well as ideas by them and the authors. 
The circular economy aspects are explored by analysing the following sections of the product-group-specific criteria documents: Product Group Definitions, the Criteria Requirements and the New Criteria. The product groups studied for the case studies are Rechargeable Batteries, Textiles and Intermediate Paper Products. The products represent different types of types of products. In addition, these groups are included in the pilot studies developed at the European Union for a Product Environmental Footprint methodology. Choosing the same product groups allows for analytical synergies between the two research processes of the project "Nordic Swan, Circular Economy and Product Environmental Footprint".

The next chapter presents an overview of the findings of the analysis of the Criteria Documents reviewed as well as case studies of product-specific criteria for three product groups. We start by presenting an overview of the findings concerning all product groups. We then present product-group-specific case studies. We also explore the role of Swan in promoting innovative models of consumption and production and discuss the role that the Swan can have in steering products in a Circular Economy direction. 



\section{Results: Circular Economy aspects in the Swan Criteria for Goods}

\subsection{Product Service Time Extension}

\subsubsection{Durability and Quality Requirements}

One of the objectives of Nordic Swan Ecolabelling is to provide good quality products. ${ }^{47}$ Most product groups for which service time extension makes sense (i.e. they are "durables" or "non-disposables") incorporated requirements for durability and quality or performance. $4^{8}$ For example:

- Furniture and Fitments (Version 4.11, 17 March 2011 - 30 June 2019): "Durability: Furniture textiles, i.e. textiles for seating, must have abrasive resistance corresponding to the rupture of the maximum of two threads at a minimum of 20,000 wear revolutions for domestic use and 40,000 for public use".49

- Toys (Version 2.0, 21 March 2012 - 31 March 2016): "Colour retention: Colour retention at washing shall be at least level $3-4$ for colour change and at least level 3-4 for discoloration. This requirement applies to washable textiles". ${ }^{50}$

Many product group criteria specify a minimum time for obligatory warranty or guarantee, ranging from 2 to 10 years..$^{11}$ For example:

- White Goods (Version 5.2, 20 June 2013-31 December 2018): "The manufacturer is to provide a warranty that the white good will work for at least two years. The warranty is to apply from the day that the machine is delivered to the customer"..$^{2}$

- Windows and Exterior Doors (Version 4.5, 19 March 2014 - 31 March 2020): "Guarantee: The window manufacturer must provide a 10-year guarantee

\footnotetext{
${ }^{47}$ Nordic Swan Ecolabel (2011), p. 2 and e.g. White Goods, p. 4.

$4^{8}$ Furniture and Fitments (R53-59, R66, and Appendix 1, 6.2), Windows and exterior doors (020), Durable/Resistant Wood for Outdoor Use (014), Floor Coverings (038), Construction and Façade Panels (034), Closed Toilet Systems (09), Supplies for Microfibre-based cleaning (R35, R41), Toys (R18), Outdoor furniture (R23, R40), Boilers for Solid Biofuels (o2), Stoves (02, 09), Textiles, Hides, Skins and Leather (K69-K79), Rechargeable Batteries (012).

49 Furniture and Fitments (R.53).

50 Toys (Ro18).

${ }^{51}$ White Goods (029), Windows and Exterior Doors (022), Heat Pumps (012), Compost Bins (020),

Closed Toilet Systems (017), Boilers for Solid Biofuels (02), Imaging Equipment (022), TV\& Projector (0.13)

$5^{2}$ White Goods (029).
} 
covering function, insulating glass unit and wood rot. The guarantee must encompass all functional requirements in the applicable/relevant standards. The exterior door manufacturer must provide a 10-year guarantee for dimensional stability and a 2-year guarantee for function". 53

\subsubsection{Upgrade and Repair}

Product design that allows for easy repair and upgrade through the availability of replacement parts is at the centre of product service time extension. Related requirements are reflected in several of the Swan criteria, in particular for electronic devices and household goods. ${ }^{54}$ Typical requirements relate to replacement parts. For example:

- TVs and projectors (Version 5.5, 20 June 2013-30 June 2020): "Requirements regarding life-time extension: The manufacturer shall offer a commercial guarantee to ensure that the product will function for at least two years. This guarantee shall be valid from the date of delivery to the customer. The availability of compatible electronic replacement parts shall be guaranteed for seven years from the time that production ceases". .55

- Computers (Version 7.4, 23 October 2013-30 June 2020): A computer must fulfil among other requirements the following: "are easy to upgrade, dismantle and recycle"..$^{5}$ In addition: "Upgradeability: A category A, B, D or F computer must be modular. The user shall be able to replace the modules without the use of special tools and it shall be possible to upgrade the computer by primary memory expansion installation, exchange and expansion of mass storage, installation and/or exchange of CD ROM, DVD and hard disk drive, at least one additional interface for external storage media and other peripheral devices" ${ }^{57}$

In addition, product service time is reflected in several disposable products, making reference to the use or operating time of the product (e.g. candles, sanitary products and primary batteries). ${ }^{58,59,60} \mathrm{In}$ the case of candles, it is required that the cups can be used several times or are biodegradable. In the case of Office and Hobby Supplies, single-use tape dispensers are not permitted, and refill cartridges must be offered for Nordic Swan Ecolabelled ballpoint pens, and consumer information on this matter must be presented (037).

\footnotetext{
53 Windows and exterior doors (022).

54 White Goods (030), Furniture and Fitments (R6o-R62), Compost Bins (020, B.8.4), Closed Toilet Systems (017), Boilers for Solid Biofuels (02), Imaging Equipment (022), TVs and projectors (013), and computers (07 upgradeability).

55 TV and Projector (013).

${ }^{6}$ Computers, p.4.

57 Computers (07).

$5^{8}$ Candles (R1, R18).

59 Sanitary Products (R43, R44).

60 Primary Batteries (og).
} 
Detergents and cleaning agents, as well as other industrial and household chemical products (paints, building chemicals), are consumables whose function is to use up the product. Therefore, the extension of the product life time itself is not an applicable goal, and the number of relevant criteria requirements is correspondingly limited. However, there are requirements aiming at the efficacy of the product and packaging requirements that promote appropriate dosage. Requirements for the resealability of packaging also tend to extend the expected use time of the product. ${ }^{61}$

\subsubsection{Multi-functionality}

One way of intensifying the use of existing products is through the design of products which serve several uses. ${ }^{62}$ This multi-functional product design is reflected in the following product-group-specific criteria:

- Rechargeable Batteries (Version 4.5, 7 December 2010 - 30 June 2018): "Charger, battery sizes: If the rechargeable batteries are sold together with a charger, the charger will be of high quality and capable of charging several sizes of battery". ${ }^{63}$

\subsection{Material Circulation}

\subsubsection{Secondary Raw Material}

Secondary raw material use is required by the product group scope definition of a number of product groups. ${ }^{64}$ For example:

- Outdoor Furniture and Playground Equipment (Version 3.6, 17 March 2011 31 March 2019): "Requirements have accordingly primarily been imposed with respect to the following: a) Wood raw materials from sustainable forestry operations. b) The use of recycled plastic and metal raw materials and a design that permits the re-use of plastic and metal. c) The use of chemicals with a lower environmental impact. d) Good performance properties (safety, strength and stability)."

Many product groups require a percentage of recycled inputs. For example:

61 Indoor Paints and Varnishes (022), Chemical Building Products (029); Office and Hobby Supplies colouring pens, paint and glue, the packaging/container must be re-sealable, so that the product does not dry out $\left(\mathrm{O}_{2} 6\right)$ and the Criteria include requirements on the writing length and resistance to dry out (031-034).

62 Mäkivuokko (2001), p.25.

63 Rechargeable Batteries (O6).

64 Furniture and Fitments, Windows and Exterior Doors, Floor Coverings, Construction and Façade Panels,

Outdoor Furniture and Fixtures and Playground Equipment, and Remanufactured Toner Cartridges. 
- Compost Bins (Version 3.0, 11 June 2014 - 30 June 2019): "Recovered plastics: Plastics used in the compost bin must contain a minimum of $30 \%$ recovered materials". ${ }^{6}$

- Floor Coverings (Version 6.2, 18 November 2014 - 31 December 2019): "Renewable and/or recycled raw materials: The flooring shall consist of: a) Minimum $60 \%$ by weight of renewable raw materials or b) Minimum $70 \%$ by weight recycled materials or $\mathrm{c}$ ) Floorings that consist of both renewable and recycled material shall comply with the following formula $(7 / 6) x X+Y \geq 70 \%$ by weight $(X=$ Percentage by weight of renewable raw materials; $Y=$ Percentage by weight of recycled materials)" ${ }^{\prime 66}$

Recycled material is defined as per $\mathrm{ISO}_{14021}$ and covers both pre- and post-consumer materials. ${ }^{67} \mathrm{New}$ Criteria chapters present the need to identify possibilities for recycled materials and enhancing recyclability through design in future criteria. ${ }^{68}$

Further requirements for recovered materials, including metal, paper, wood, plastic and gypsum, may be noted in a broad range of product groups, either as requirements, as an option in a requirement or as an advantageous factor in material content calculation formulae. ${ }^{69}$ For certain product groups that are in contact with the human body (Sanitary Products) or with food (Disposables for Food), the use of recycled fibre or post-consumer recycled materials is not permitted due to health reasons. ${ }^{70}$ Use of residues defines products such as biogas and biofuel pellets. Criteria for "Fuel and Biogas for Heating and Industrial Use" make reference to fuel production from waste and residues. Raw materials from ecolabelled biofuel pellets are generally from saw dust or planer shavings from saw mills (wood chips). ${ }^{71}$

Requirements for reusing recovered components are present in the criteria for Imaging Equipment (06) as well as Remanufactured Toner Cartridges. For example:

- Imaging Equipment (Version 6.3, 20 June 2013-31 December 2019): "Products with combined toner cartridge may be accepted if the cartridge is not designed to prevent re-use. Products must accept re-manufactured toner cartridges. In order

\footnotetext{
${ }_{5}$ Compost Bins ( $\left.\mathrm{RO}_{3}\right)$.

${ }^{66}$ Floor Coverings ( $\left.\mathrm{O}_{2}\right)$.

67 "Recovered plastics shall apply to the definition of recovered plastics in the standard ISO 14021 . According to ISO 14021 recovered material is defined as post-consumer recovered material, such as scrapped plastics products or packaging or preconsumed material, such as reprocessed production waste. Production waste (scrap, rework, regrind) which can be directly reused in the process is not regarded as recycled". E.g. Compost Bins ( $\left.\mathrm{RO}_{3}\right)$.

${ }^{68}$ TVs and Projectors, Computers, Machines and Parks for Gardens, Compost Bins, Construction and Façade Panels, Hobby Supplies.

69 Furniture and Fitments (R21, R27, R28, R35), Outdoor Furniture and Fixtures and Playground Equipment (R10, $\left.\mathrm{R}_{13}, \mathrm{R}_{29}, \mathrm{R}_{3} 6\right)$, Imaging Equipment $\left(0_{4}, 06,015\right)$, Toys $\left(\mathrm{R}_{3} 8\right)$, Windows and Exterior Doors $\left(\mathrm{O}_{5}\right.$, Floor Coverings $\left(\mathrm{O}_{2}\right)$, Construction and Façade Panels $\left(\mathrm{O}_{5}, \mathrm{O}_{10}, \mathrm{O}_{11}\right)$, Compost Bins ( $\left.\mathrm{O}_{3}\right)$, Supplies for Microfibre-based Cleaning R4, R28, $\left.\mathrm{R}_{32}\right)$, Small Houses (02, 025, P21), Remanufactured Toner Cartridges, Machines for Parks and Gardens (014), Computers (017) and TVs and Projectors (012)

${ }^{70}$ Sanitary Products: Off-cuts from production are not classified as recycled fibre and may therefore be used; on a year-onyear basis a minimum of $75 \%$ of raw materials in the pulp must be wood shavings or saw dust (R6). If paper contains recycled fibres, the content of harmful chemicals must be limited (R10).

${ }^{71}$ Biofuel pellets, Definitions, p. 16
} 
to ensure that the toner cartridges are returned for re-use, a return system must be offered for re-cycling combined toner cartridges and information to user about the return system must be provided". ${ }^{2}$

The Swan criteria include one product group specifically focusing on a remanufactured product. ${ }^{73}$ The product group is defined so that new products are not permitted at all. Remanufactured OEM Toner Cartridges product group by definition focuses on a remanufactured and reassembled cartridge with toner powder, drum and the necessary drive mechanism. Criteria specify the reuse and take-back requirements and promote upgradability: ${ }^{74}$

- $\quad$ "Reuse: The toner cartridge or container must be used by the consumer and then collected, cleaned, checked for defects, repaired and refilled with toner powder. The remanufactured OEM toner cartridge must comprise a minimum of $75 \%$ by weight recycled parts, as an average of at least 100 units. Future Criteria will consider whether the scope will be extended to other product groups and on improved take-back systems (R10)."

- "To ensure that the products are returned for recycling, a cartridge take-back system must be in place. Agreements between the manufacturers and distributers/resellers shall include a clause stating that the distributer/reseller shall, via their website, provide a take-back system as specified below. Noncommercial consumers must be able to return individual toner cartridges free of charge. The licensee may also recommend other free methods of returning single toner cartridges for consumers. The return system may comprise one or more of the following measures: Collection boxes located at customer and reseller's premises. Such collection boxes must be available free of charge from the licensee. The return of such collection boxes to the licensee must also be free of charge for corporate customers of the licensee/distributor/reseller; Deposit system; Prepaid address label or packaging for return supplied with individual products (R11).

The future criteria will consider whether the scope will be extended to other product groups and will look into improved take-back systems.

The use of secondary raw materials in packaging is highlighted in diverse product groups. ${ }^{75}$ For detergent and related product groups the proportion of packaging compared with the product is expressed as the Weight to Utility Ratio (WUR). It encompasses a post-consumer recycled material content in packaging. The WUR measures the amount of packaging that is used to deliver a quantity of the product with

\footnotetext{
72 Imaging Equipment (06).

73 Remanufactured OEM Toner Cartridges (Version 5.2, 15 June 2012 - 30 June 2018).

74 Remanufactured OEM Toner Cartridges, (R10 and R11).

75 Primary Batteries (03) Imaging Equipment (015), Machines for Parks and Gardens (014) and Computers (017) and others,

including cleaning substances.
} 
a predetermined benefit to reduce packaging and promote the use of recycled materials. ${ }^{76}$ The "Reuse Factor" of the WUR equation denotes the times that the packaging component is used for the same function. ${ }^{77}$ It promotes the reuse and refilling of the packaging container..$^{78}$

\subsubsection{Recycling and Recyclability}

Recycling in process and of the product, as well as packaging, is included in one form or another as a requirement in all criteria documents. Relevant national regulations (including producer responsibility, where relevant), legislation and agreements regarding take-back must be met and consumers must be appropriately informed. ${ }^{79}$ The criteria for "Small Houses, Apartment Buildings, Schools and Pre-schools" offers additional points for a high percentage of sorting and recovery/recycling of building waste. ${ }^{80}$

Requirements on dismantling and material separability, for the purpose of facilitating recycling, exist in numerous product groups ranging from furniture to electronic equipment and disposables and packaging. ${ }^{81}$ For example:

- Outdoor Furniture and Fixtures (R28) "Metal parts in the product must be separable from other materials in the product without the use of special tools to facilitate reuse".

- TV and Projector (011): "The manufacturer shall demonstrate that the product can be easily dismantled by professionally trained recyclers, using the tools usually available to them".

- Disposables for Food ( $\mathrm{O}_{27}$ ): "Packaging produced by combining materials must be suitable for material recycling".

In addition, the use of DIN coding is suggested as one way of informing about the plastic type of packaging that goes to recycling. ${ }^{82,}{ }^{83}$ Recycling may also be facilitated or limited by the chemical content. The Swan criteria consist of a significant proportion of chemical-related criteria which may contribute towards recyclability.

\footnotetext{
$7^{6}$ E.g. Hand Dishwashing Detergents (R16).

77 There are requirements related to WUR in the Criteria Documents for Dishwasher Detergents and Rinsing Agents (014), Hand Dishwashing Detergents (R16), Floor Care Products (R19), Laundry Detergents and Stain Removers (R14), and Cleaning Products (R19).

${ }^{78}$ Cosmetics (R27), Hand Dishwashing Detergents (R16), Floor Care Products (R19), Cleaning Products (R19),

Laundry Detergents (R14).

79 The following text is found in all reviewed product groups: Relevant national regulations, legislation and/or trade agreements regarding take-back systems for products and packaging must be complied with in all the Nordic countries where the Nordic Swan Ecolabelled product is marketed.

${ }^{80}$ Small Houses, Apartment Buildings, Schools and Pre-schools (P13).

${ }^{81}$ Furniture and Fitments (R26), Windows and Exterior Doors (013), Outdoor Furniture and Fixtures (R28), Imaging

Equipment (05, 09), TV and Projector (011), Disposables for Food (027), and Cosmetics (Packaging), R28.

82 DIN Standards Website.

${ }_{3} 3$ Hand Dishwashing Detergent (R15), Dishwasher Detergents for Professional Use (R16), Industrial Cleaning (016),

Cleaning Products (R18), Dishwasher Detergents (020).
} 
Several of the "New Criteria" chapters indicate further future considerations that can facilitate separability. For example, the criteria for the product groups "Boilers for Solid Biofuel" and "Machines for Parks and Gardens" and include suggestions that will make dismantling and material recycling easier. ${ }^{84}$ For example, the "Machines for Parks and Gardens" highlights that in the future machines are to be constructed to enable reuse or materials recycling of certain material share. ${ }^{85}$

\subsection{Case Studies}

The three product groups analysed here have been selected as case studies for the project "Nordic Swan, Circular Economy and Product Environmental Footprint" and are aligned with a selection of product groups from the Product Environmental Footprint (PEF) pilot studies of the European Union.

\subsubsection{Case Study: Rechargeable Batteries and Accumulators}

Table 4 presents how the Swan criteria document for Rechargeable Batteries takes into account product service time extension, circulation of materials from the waste stream and resource efficiency, as per criteria presented in the criteria document "Nordic Swan Ecolabelling of Rechargeable Batteries, Version 4.5, 7 December 2010 - 30 June 2018". The Nordic Swan Ecolabel defines rechargeable batteries according to the European Union's Batteries Directive 2006/66/EC.

Criteria are divided under Environmental Requirements, Packaging and Information, Working Conditions, Efficiency/Quality, Quality Requirements and the Requirements of the Authorities. The chapter on New Criteria, to be possibly included in the forthcoming revisions of the criteria document, proposes further requirements on toxic substances in the production process, energy use in the production process, transport and consumer information. The criteria for Rechargeable Batteries is based on the consideration that the battery will need to be replaced less frequently than nonrechargeable (primary, disposable) batteries, thereby saving the environment from the burden of more batteries. ${ }^{86}$ This analysis excludes Nordic Swan Ecolabel criteria for primary (disposable) batteries. Also, criteria of other products, that include rechargeable batteries, were examined. These are Computers (Version 7.3, 23 October 2013 - 30 June 2019), Toys (Nordic Swan Ecolabelling of Toys, version 2.2., 21 March 2012 - 31 March 2013), Imaging Equipment (v. 6.3, 20 June 2013 - 31 December 2019) and Machines for Parks and Gardens (Version 5.3, 13 March 2013-31 March 2019).

\footnotetext{
84 Machines for Parks and Gardens, p. 20, Boilers for Solid Biofuel, p. 17.

85 Machines for Parks and Gardens, p.20.

${ }^{86}$ Nordic Swan Ecolabelling of Rechargeable Batteries, p.3.
} 
Table 4: Requirements relevant to Circular Economy in the Nordic Swan Ecolabel Criteria for Rechargeable Batteries

\begin{tabular}{|c|c|c|c|c|c|c|c|c|c|c|c|c|c|}
\hline \multirow{2}{*}{$\begin{array}{l}\text { Criteria for Rechargeable Batteries version } 4 \text { (valid } \\
7 / 12 / 2010-30 / 6 / 2018 \text { ) Battery requirements in the criteria } \\
\text { for Computers and Machines for Parks and Gardens }\end{array}$} & \multicolumn{4}{|c|}{ Extension of Product Service Time } & \multicolumn{6}{|c|}{ Circulation of Materials } & \multicolumn{3}{|c|}{ Resource Efficiency } \\
\hline & Durability & $\begin{array}{l}\text { Repara- } \\
\text { bility }\end{array}$ & $\begin{array}{l}\text { Upgrada- } \\
\text { bility }\end{array}$ & $\begin{array}{c}\text { Multi- } \\
\text { functionality }\end{array}$ & $\begin{array}{l}\text { Recycla- } \\
\text { bility }\end{array}$ & $\begin{array}{l}\text { Non-toxic } \\
\text { cycles }\end{array}$ & $\begin{array}{l}\text { Recycled } \\
\text { content }\end{array}$ & $\begin{array}{l}\text { Recycling } \\
\text { in } \\
\text { production }\end{array}$ & $\begin{array}{l}\text { By-product } \\
\text { utilisation }\end{array}$ & $\begin{array}{l}\text { Recycling of } \\
\text { Product } \\
\text { (E-o-L) }\end{array}$ & $\begin{array}{c}\text { Water } \\
\text { Efficiency }\end{array}$ & $\begin{array}{l}\text { Energy } \\
\text { Efficiency }\end{array}$ & $\begin{array}{l}\text { Material } \\
\text { Efficiency }\end{array}$ \\
\hline
\end{tabular}

\section{Rechargeable Batteries (RB).}

02 Metal Content: The metal content should not exceed

specified limits (mercury, cadmium, lead and arsenic).

03 Nanotechnology: Nanotechnology may only be present for

the purpose of increasing energy efficiency.

04 Information on batteries containing nanoparticles: The

producer must publish information on how batteries

containing nanoparticles are to be handled by battery

recycling firms.

05 Plastic in battery chargers: The casing must not be

chlorinated plastic, cadmium, lead, chloro-paraffins, and

halogenated organic flame-retardants, and other flame

retardants with specified risk classifications must not be

present in casing \& cables.

06 Charger, battery sizes: The charger must be suitable for use with a minimum of two battery sizes.

o7 Packing: Chlorinated packaging must not be used.

08 Primary packaging, recycled portion: Proportion of post-

consumer recycled material in the primary packaging must be

at least $80 \%$ of weight. 


\section{Criteria for Rechargeable Batteries version 4 (valid}

$7 / 12 / 2010-30 / 6 / 2018$ ) Battery requirements in the criteria

for Computers and Machines for Parks and Gardens

Durability

Extension of Product Service Time

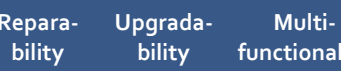

ractis
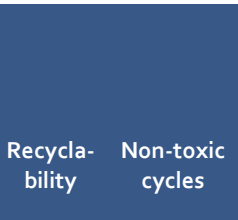

Circulat

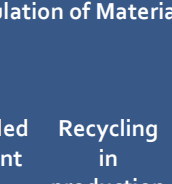

B

By-product
utilisation

og Collection system for batteries and packaging. 012 Quality of rechargeable batteries: Cycle life

testing/endurance testing are performed to ensure number of charge/discharge performance.

013 Charger Quality: Charger must automatically stop

charging when battery is fully charged; requirements relating

to maximum trickle charge and maximum no-load current.

\section{Computers (C).}

03 Energy and Power Consumption of Computers: It must be possible to swap the battery. A replacement battery must be available as an option or spare part.

\section{Machines for Parks and Gardens ( $M$ ).}

011 Battery Quality and Performance: The machine must be

designed to switch off when the battery reaches a "minimum power level" pre-established by the manufacturer.

Resource Efficiency

\begin{tabular}{|c|cc} 
Water & Energy & Material \\
Efficiency & Efficiency & Efficiency \\
\hline
\end{tabular}

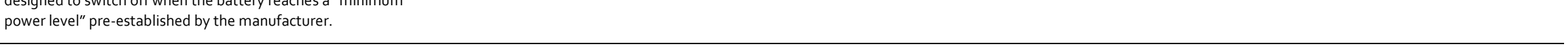




\subsubsection{Case Study: Textiles, Hides/Skins and Leather (includes products for apparel and furnishings)}

Table 5 indicates how the Nordic Swan Ecolabel takes into account Circular Economy aspects, as per criteria presented in the criteria document "Nordic Swan Ecolabelling of Textiles, Hides/Skins and Leather", Version 4.3,12 December 2012 - 31 December 2018.

The criteria require the use of recycled fibres, such as fibres from excess materials from the textile and clothing industry or from collected textile waste or from plastic waste. Recycled fibres do not need to fulfil the requirements for the production of fibres ${ }^{87}$ Criteria that address the use of recycled fibres and the quality factors (e.g., colour fastness and shrinkage) are seen to be factors that underpin the circular economy.

The Criteria for Textiles, Hides/Skins and Leather focus in particular on the production and treatment of fibres and hides/skins, especially in terms of limiting chemical content. ${ }^{88}$ Over half of the requirements are on chemicals. However, we consider here that only those chemicals for which toxic residues are present in the final product and which act as a barrier for reuse of material, or conversely, where the lack of a hazardous chemical facilitates recycling, are relevant to the recyclability and non-toxic cycles.

The Criteria Document furthermore indicates New Criteria relating to sourcing, chemicals and evaluation of requirements related to environmental factors in production of different kinds of fibres. Of those criteria, a re-evaluation of the requirements to energy consumption and water consumption of wet treatment can be considered to contribute to added resource efficiency.

\footnotetext{
${ }^{87}$ Nordic Swan Ecolabelling of Textiles, Hides, Skins and Leather (K2).

${ }^{88}$ In some cases, these criteria may contribute to the recyclability of the product, but a further assessment would need to be done on this.
} 
Table 5: Requirements relevant to Circular Economy in the Nordic Swan Ecolabel Criteria for Textiles, Hides, Skins and Leather

\begin{tabular}{|c|c|c|c|c|c|c|c|c|c|c|c|c|c|}
\hline \multirow{2}{*}{$\begin{array}{l}\text { Criteria for Textiles, hides/skins and leather Version } 4 \\
\text { (valid 12/12/2012-31/12/2018) }\end{array}$} & \multicolumn{4}{|c|}{ Extension of Product Service Time } & \multicolumn{6}{|c|}{ Circulation of Materials } & \multicolumn{3}{|c|}{ Resource Efficiency } \\
\hline & Durability & $\begin{array}{l}\text { Repar- } \\
\text { ability }\end{array}$ & $\begin{array}{l}\text { Upgrad- } \\
\text { ability } \\
\text { (N/A) }\end{array}$ & $\begin{array}{l}\text { Multi- } \\
\text { functio- } \\
\text { nality }\end{array}$ & $\begin{array}{l}\text { Recycl- } \\
\text { ability }\end{array}$ & $\begin{array}{l}\text { Non-toxic } \\
\text { cycles }^{89}\end{array}$ & $\begin{array}{l}\text { Recycled } \\
\text { content }\end{array}$ & $\begin{array}{l}\text { Recycling } \\
\text { in produc- } \\
\text { tion }\end{array}$ & $\begin{array}{l}\text { By- } \\
\text { product } \\
\text { utilisa- } \\
\text { tion }\end{array}$ & $\begin{array}{l}\text { Recycling } \\
\text { of } \\
\text { Product } \\
\text { (E-o-L) }\end{array}$ & $\begin{array}{l}\text { Water } \\
\text { Efficiency }\end{array}$ & $\begin{array}{l}\text { Energy } \\
\text { Efficiency }\end{array}$ & $\begin{array}{l}\text { Material } \\
\text { Efficiency }\end{array}$ \\
\hline
\end{tabular}

K20 Requirements for recycling: A minimum of $90 \%$ of all

production waste from manufacturing of latex and

$\mathrm{x}$

polyurethane shall be recycled.

$K_{37}$ Sizing agents: At least $95 \%$ (dry weight) of the

components of sizing agents applied to yarns shall be

sufficiently biodegradable. If they are not sufficiently

biodegradable, they shall be recycled.

K65 Water consumption: The annual average water

consumption during the tanning of hides/skins and leather

shall not exceed $25 \mathrm{~m} 3 /$ tonne of raw hides. 90

K69 Dimensional changes during washing and drying:

Dimensional changes during washing and drying shall not

exceed specified percentages.

K70 Colour fastness to washing: Colour fastness to washing

shall be at least level 3-4 for colour change/discolouration.

K71 Wet rubbing: Shall be at least level 2-3.

K 72 Dry rubbing: Shall be at least level 4

$\mathrm{K}_{73}$ Colour fastness to light-textiles: Shall be at least level 5 .

$x$

$x$

${ }^{89}$ No "crosses" indicated, but the significant number of chemical-related restrictions may be considered to contribute to recyclability and non-toxic cycles. For this study, we did not specify which chemical requirements would contribute towards that end.

${ }_{90}$ Compare with BREF document for Tanning Hides and Skins, which states that the water consumption of these processes can be reduced to $12-25 \mathrm{~m}^{3}$. For example, the water consumption of some tanneries in Germany is $15-20$ m3/tonne. 


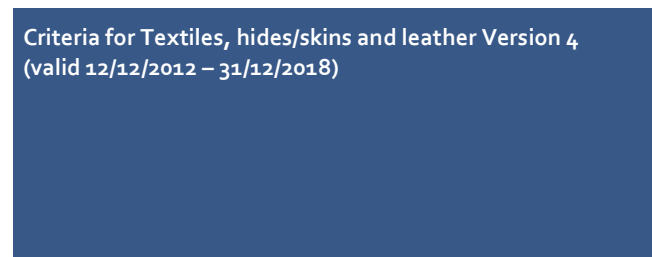

K74 Pilling: Furniture fabrics shall have a pilling resistance equivalent to level 4

K76 Tear strength of leather: Shall be over $20 \mathrm{~N}$.

$\mathrm{K} 77$ Bending test: Shall achieve 20,000 test repetitions without visible damage.

K78 Colour fastness to light-hides/skins and leather: Shall be at least level 3 for leather with a surface coating.

K79 Wear test: Shall be at least level 3.

M7: Recycling and return system: relevant regulations and industry agreements.

\begin{tabular}{|l|c|cc|}
\multicolumn{3}{|c|}{ Extension of Product Service Time } \\
Durability & $\begin{array}{c}\text { Repar- } \\
\text { ability }\end{array}$ & $\begin{array}{c}\text { Upgrad- } \\
\text { ability } \\
\text { (N/A) }\end{array}$ & $\begin{array}{c}\text { Multi- } \\
\text { functio- } \\
\text { nality }\end{array}$ \\
& &
\end{tabular}

$x$

$x$

\begin{tabular}{|c|c|c|c|c|c|c|c|c|}
\hline \multicolumn{6}{|c|}{ Circulation of Materials } & \multicolumn{3}{|c|}{ Resource Efficiency } \\
\hline $\begin{array}{l}\text { Recycl- } \\
\text { ability }\end{array}$ & $\begin{array}{c}\text { Non-toxic } \\
\text { cycles }^{9^{1}}\end{array}$ & $\begin{array}{l}\text { Recycled } \\
\text { content }\end{array}$ & $\begin{array}{l}\text { Recycling } \\
\text { in produc- } \\
\text { tion }\end{array}$ & $\begin{array}{l}\text { By- } \\
\text { product } \\
\text { utilisa- } \\
\text { tion }\end{array}$ & $\begin{array}{l}\text { Recycling } \\
\text { of } \\
\text { Product } \\
\text { (E-o-L) }\end{array}$ & $\begin{array}{c}\text { Water } \\
\text { Efficiency }\end{array}$ & $\begin{array}{l}\text { Energy } \\
\text { Efficiency }\end{array}$ & $\begin{array}{c}\text { Material } \\
\text { Efficiency }\end{array}$ \\
\hline
\end{tabular}

${ }_{91}^{1}$ No "crosses" indicated, but the significant number of chemical-related restrictions may be considered to contribute to recyclability and non-toxic cycles. For this study, we did not specify which chemical requirements would contribute towards that end. 


\subsubsection{Case Study: Intermediate Paper Products}

Table 6 indicates how the Nordic Swan Ecolabel criteria for Paper Products (Basic Module and Chemicals Module) take into account Circular Economy, as per criteria presented in the document "Nordic Swan Ecolabelling of Paper Products-Basic Module, Version 2.1, 22 June 2011 - 30 June 2016 and Chemicals Module, Version 2.3, 22 June 2011-30 June 2016. The Basic Module sets out criteria mainly relating to pulp and paper production. ${ }^{92}$ In addition to the Basic Module and Chemicals Module, the Nordic Swan Ecolabelling criteria comprise supplementary modules for copy and printing paper, tissue paper, greaseproof paper and paper envelopes, all of which refer to the Paper Products' basic module.

Criteria are divided under: Regulatory requirements; Quality and environmental assurance; Fibre raw material; Chemicals; Energy and $\mathrm{CO}_{2} ;$ Emissions to water and air; Waste; and Annual reporting. Future requirements include consideration of the quantities of certified fibres. Recycled fibre is defined as: "fibre collected from converter and post-consumer stages. Purchased broke and broke generated within the mill are defined as new fibre if the fibre raw material is new fibre, and as recycled fibre if the raw material is recycled fibre" ${ }^{\prime 93}$

The Chemicals module Version 2.3, 22 June 2011 - 30 June 2016 includes requirements in regard to the uses of chemicals in the manufacture of pulp and paper. 94 Further product-specific criteria for final paper products are specified in the criteria documents for Copy and Printing Paper, Greaseproof Paper and Tissue Paper and Printing Companies. Examples of criteria that are set in the criteria documents for final products include requirements for chlorine free plastics (Tissue Paper R15), exclusion of PVC use (Printing Companies 07), limitations on the use of recycled fibre due to contact with food (Greaseproof paper 03, Tissue paper R10), coating and impregnation chemicals (Greaseproof Paper og). Printing companies' future criteria for printing inks may include a requirement to prevent problematic substances in materials manufactured from recycled paper.

\footnotetext{
$9^{2}$ This is in line with the EC's Product Environmental Footprint (PEF) Pilot, which targets intermediate products of paper, i.e., graphics, packaging papers and tissue paper grade when it exits the paper mill's gate.

93 Paper Basic module, p. 17.

94 Cleaning agents, de-inking chemicals, biocides/slimicides, coatings, retention agents, foam inhibitors/de-foamers and wet-strength agents, dyes (heavy metals, amines, phthalates), and adhesives.
} 
The product definitions include elements that help recyclability. The Criteria document for Tissue Paper (5.5) excludes paper products containing cleaning agents, viscose-containing products and paper laminated with non-cellulose based materials. ${ }^{95}$ New Criteria for Printing Companies, Printed Matter, Envelopes and other Converted Paper Products (5.10) will consider establishing requirements for printing inks to prevent problematic substances in materials manufactured from recycled paper. ${ }^{96}$

It is considered that extending the product life time for intermediate paper-based products is not applicable. Hence, Product Service Time Extension is not included in the table.

95 Nordic Swan Ecolabelling of Tissue paper, p.4.

${ }^{96}$ Nordic Swan Ecolabelling of Printing Companies, Printed Matter, Envelopes and other Converted Paper Products, p.32. 
Table 6: Requirements relevant to Circular Economy in the Nordic Swan Ecolabel Criteria for Paper

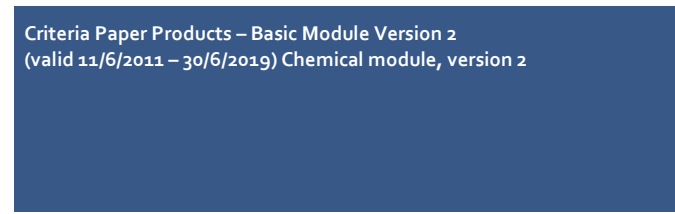

Basic Module R7c Certification of Fibre Raw Material: On an

annual basis, at least $30 \%$ of fibre raw material in the paper shall

be sourced from certified areas, or $75 \%$ of the fibre raw material

in the paper must be recycled fibre, wood shavings or sawdust.

A combination is possible.

Basic Module Rg Total Energy Score: Maximum energy scores specified must be fulfilled.

Basic Module R17 Waste: The pulp/paper manufacturer must specify that all waste types generated in the factory area must be sorted at source and the various waste fractions shall be recycled or reused to as great an extent as possible.

Basic Module R17 Waste: Combustible waste containing wood with a positive thermal value must not be sent to landfill.

\begin{tabular}{|c|c|c|}
\hline Recyclability & $\begin{array}{l}\text { Non-toxic } \\
\text { cycles }\end{array}$ & $\begin{array}{l}\text { Recycled } \\
\text { content }\end{array}$ \\
\hline
\end{tabular}

Recycling in
production

By-product
utilisation

Resource Efficiency

Re
Water
Efficiency

\section{Chemical Module. 97}

R6: Coating agents, retention agents, flocculants, foam

inhibitors/defoamers and wet strength agents: Limits the use of

chemicals.

Rg: Dyes for use in printing and colouring shall contain a maximum total of $2 \%$ by weight of constituent substances

classified as environmentally hazardous. Exception to the

requirement are dyes where dyestuffs are fixed to fibres >98\%

and where the constituent substances are not found in lists

specified in the requirement.

${ }_{97}$ The relevant criteria on chemicals were identified by Terhi Uusitalo, Chemical Expert of the Nordic Swan Ecolabelling, Finland. 
dyes (applies to dyeing pulp and printing inks).

R11: Direct and pigment dyes shall not contain dye substances that may liberate the amines specified.

R12: Phthalates shall not be present in the dyes used.

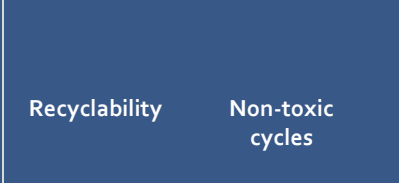

recycled

Recycled

content

Greaseproof Paper $40(18 / 11 / 2014-31 / 12 / 2018)$

03 Only virgin fibre may be used in the pulp used to manufacture the paper (contact with food).

og Chemicals added to the pulp or to impregnation/coating must not contain chromium or fluoride compounds.

Printing Companies, Printed Matter, Envelopes and other Converted Paper Products 5.9 (15/12/2011 - 31/12/2017).

06 Pressure-sensitive adhesives must not damage the recycling process (INGEDE's test).

o7 Packaging and laminates must not contain PVC.

M10 Nordic Swan Ecolabelled printed matter must not contain

Tissue Paper 5.5. (11/10/2011 - 31/12/2019).

R10 Compliance with 1935/2004/EC of materials and articles

intended to come into contact with food.

R15 Chlorine-free plastics: Packaging made from a combination of materials must be suitable for recycling. 


\section{Swan and Innovative Forms of Consumption and Production}

The previous chapter described the types of requirements that have been set that are in line with Circular Economy. However, in addition to extending the service life of products and enhancing material circulation, central to the concept of Circular Economy are innovative forms of consumption and production. These may include e.g. shared-use business models, where a product's utilisation is improved by sharing it across a significant number of consumers during its use phase, ${ }^{98}$ and remanufacturing, which involves returning an end-of-life product to like-new or better performance with corresponding warranty. ${ }^{99}$ This section explores the role and opportunities of the Nordic Swan Ecolabel in promoting innovative consumption and production models.

\subsection{Criteria Setting for Innovative Product Groups}

Within the scope of the Ecolabel criteria development the Nordic Swan Ecolabel has the potential to include incentives for innovations in three ways: (a) into existing criteria, (b) as extensions to criteria, and (c) as a separate criteria set through a parallel faster process of criteria development. The Swan criteria are generally developed for large established product groups, in order to create a market pull for products with a better environmental performance. Generally innovative products are small product groups, meaning that the criteria development process is relatively heavy and resource consuming, considering that the market potential of innovative products, is not certain. The following presents illustrative case studies of how the process for innovative product groups has been handled in the past.

Fast track for a new set of criteria: The Environmental Pioneer (Fast track) Pilot, implemented by the Nordic Swan Ecolabel targeted small innovative product groups and allowed a quicker criteria development process for products that have a clear (and not only marginally better) advantage in their environmental performance.

\footnotetext{
${ }^{98}$ Ellen MacArthur Foundation (2015a), p.32.

${ }^{99} \mathrm{EC}(2015)$, p. 5.
} 
Criteria were developed only for products that had already been developed, had the potential to enter into the market and to be profitable, and had a distribution plan in the Nordic countries. The Nordic Swan Ecolabelling organisation did not apply the "30\% rule" and sought out good products to respond to the priority areas. ${ }^{100}$ Microfibre Cloths is an example a of product group that went through a separate accelerated "fast track" development process in 2003. The Microfibre cloth criteria became popular and there are many license holders for the formerly small innovative product in the Nordic countries.

Using existing criteria: This is a model that can be used to strengthen the existing criteria set with more innovative elements. The updated criteria for "Small houses, apartment buildings and buildings for schools and pre-schools, version 3.0" include a point criterion $\mathrm{P}_{14}$ for green action and innovations. Innovations relate to ecosystem services (green roofs, reuse of rain water, urban farming, diverse gardens), logistics (facilitation of cycling, electric vehicle charging point) and energy actions (smart measurement, energy storage, district heating etc.). Additional points can be gained for the award of the assessment of ecolabel criteria compliance.

Extending existing criteria: Supplementing existing criteria can be a way to address innovativeness when a similar product group with a criteria set already exists. In 2015 this was done for the vehicle fuel product group. As the product (biogas) composition is the same for transport and for industrial use, it was regarded that many of the criteria may be the same for both product groups. This, together with collaboration with the license holder for vehicle biofuel, meant that the criteria extension could be prepared within four months.

\subsection{Example: Remanufactured OEM Toner Cartridges}

The clearest example of a model of innovative production among the product groups that may be certified under the Swan Ecolabelling scheme is Remanufactured Original Equipment Manufacturers (OEM) Toner Cartridges. This product group is the only one that is directly defined through remanufacturing. Remanufacturing has been identified as a model of production that is central in the scope of transition to the Circular Economy. Remanufacturing denotes a process that includes, for example, repair, dismantling, change of parts and rebuilding of a similar or a better product. It is most economical for high value, durable, modular products that are using technology with a long life time. ${ }^{101}$ Remanufacturing is already a part of the business model of OEM in certain sectors, such as workshop industry. ${ }^{102}$

\footnotetext{
${ }^{100}$ Nordic Swan Ecolabelling (2005).

${ }^{101}$ Seppälä et al. (2016), p.24.

102 Sitra (2014), p. 9 and p. 15.
} 
The Nordic Swan Ecolabelling Criteria for Remanufactured OEM Toner Cartridges specify that Ecolabelled Remanufactured toner cartridges are "reused, after refurbishment and refilling, as toner cartridges, drum units or containers for toner powder", the objective being to reduce the consumption of energy and raw materials and waste. Requirements $R 10$ and $R 11$ set specifications for reuse, collection and takeback systems. In line with R 10, a remanufactured OEM toner cartridge comprises a minimum of $75 \%$ by weight recycled parts. The chapter on New Criteria indicates that there is consideration to expand the product group to other types of printing method, inks and manufacturing methods. ${ }^{103}$ Since the adoption of the criteria in 2012, 25 companies have received licenses. ${ }^{104}$

${ }_{103}$ Nordic Swan Ecolabelling of Remanufactured OEM Toner Cartridges, p.18.

${ }^{104}$ Nordic Swan Ecolabelling website (Finnish version). 



\section{Discussion}

\subsection{Circularity in Swan Ecolabel Criteria}

Circular Economy is very much about ensuring that materials are kept in circulation for as long as possible. By setting requirements on the use of recycled feedstock and components, the Swan can have a role in steering towards this direction. The currently valid Swan criteria include requirements on the use of recycled materials in product compositions as well as in packaging. In addition to existing requirements on the use of secondary raw materials and recycling, strengthened requirements on by-product use in manufacturing and the reuse of components would enhance material circulation. Remanufacturing is only addressed in one product group and requirements relating to dismantling are found in some product groups only. Requirements on separability of materials can be set, but is difficult to know which chemicals remain after the recycling process, and recycled materials can be a source of contamination of foodstuffs. ${ }^{105} \mathrm{Given}$ that the ecolabel takes a precautionary approach to hazardous chemicals, it could be expected that ecolabelled products lead to recycled materials with lower quantities of hazardous substances. It may, therefore, have a role in addressing non-toxic cycles. However, this issue would require a separate analysis.

The Swan aims to provide good quality products through durability, quality and warranty requirements. In addition to durability requirements, a product's service time can be extended through repair and upgrade. Requirements on repair and upgrade exist only to a limited extent in the currently valid ecolabel criteria. Nevertheless, there are product groups, such as imaging equipment and remanufactured toner cartridges that include obligations that enhance reparability. For the purposes of this analysis it was considered that the requirement for rechargeable battery chargers to be used for two different battery sizes, does promote more intense use of the product. Whilst multifunctionality has not been highlighted in circular economy literature, the authors of this analysis consider that multi-functional products have a role in enhancing the intensity of product use.

The analysis indicates a trend towards enhancing the circular approach in setting the Swan criteria. The New Criteria chapters for product groups such as Boilers for Solid Biofuels, Machines for Parks and Gardens, TVs and Projectors, Computers, Compost Bins, Construction and Facade Panels, Office and Hobby Supplies, and Remanufactured OEM Cartridges indicate that circularity will be further emphasized in the future. The indication of possible future criteria can drive product design so that it is already better aligned with Circular Economy.

105 Nordic Swan Ecolabel (2017b), p.25-26. 
To strengthen the assessment of circularity in the RPS process associated with criteria setting or revision, the framework presented in Figure 6 could be used noting that many requirements would relate to the way in which the product is designed. The aspects in bold font are those that are included in the Swan criteria today only to a limited extent or not at all.

Figure 6: Framework for future criteria development

EXTENDING PRODUCT

SERVICE TIME

$\checkmark$ Durable

$\checkmark$ Upgradable MATERIAL CIRCULATION

$\checkmark$ Reparable $\checkmark$ Modular

$\checkmark$ Multi-functional $\quad \checkmark$ Separable

MATERIAL CIRCULATION

Secondary raw materials

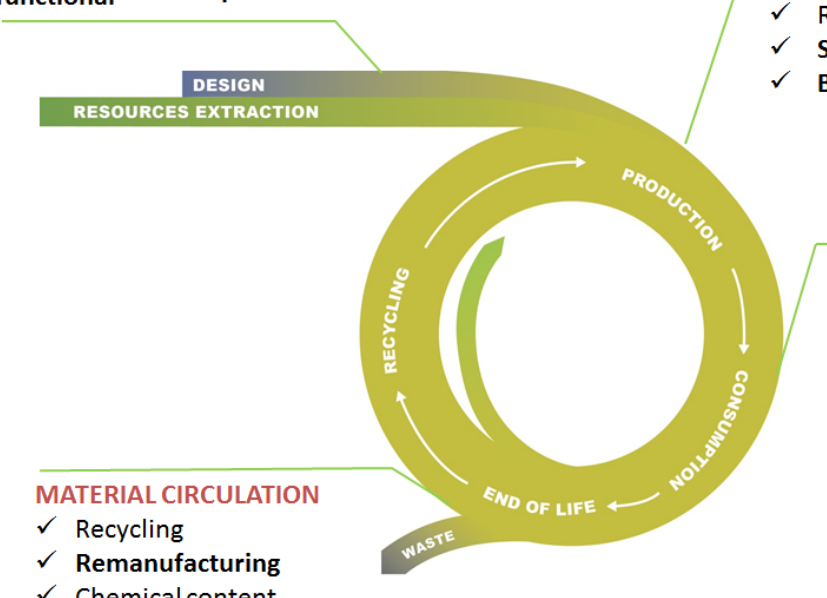

EXTENDING PRODUCT

SERVICE TIME

$\checkmark$ Sharing economy

services

\subsection{Addressing Innovative Product Groups}

The transition to a Circular Economy will benefit from innovative models of consumption (e.g. sharing, leasing) and production (e.g. remanufacturing, industrial symbiosis). There is a growing market for more service and sharing-based models of consumption that are linked to lower environmental impacts of consumption. In future criteria development, the Swan is considering how to integrate sharing and leasing systems could fit into ecolabelling criteria. For example, clothing subscription services, and redesigned clothes have been seen as potential future product groups. ${ }^{106}$

The Swan has been designed as a value-added mark for the best one-third of products in a product group. It is not intended for small product groups whereas often innovative and new products have small markets. However, the Swan has a history of trying out a process for innovative products and it could be in a position to differentiate the environmentally best sharing economy services and could extend the remanufacturing principle to other product groups.

\footnotetext{
106 For example, the Danish company Vigga offers a clothing subscription service for children's clothes and the Swedish Ecolabel Good Environmental Choice ("Bra Miljöval") includes second hand and redesign (Vigga website, Swedish Society for Nature Conservation website).
} 
Many sharing economy services develop quickly and ecolabelling should also develop the criteria sets quickly in order to steer the service development and consumption of the services. One possibility could be to combine a kind of "framework criteria set" and an additional "fast-track" criteria set, the former being a general criteria set for typical properties of sharing economy services, and the latter being specified for the service in question. The past experiences of the "fast track" process offer a good corner stone for developing a new procedure, developed especially for sharing economy services. The fast-track procedure would then just specify the framework criteria for each type of new service.

\subsection{Role of the Nordic Swan Ecolabelling in Circular Economy}

An internal document of the Nordic Swan Ecolabel proposed how the Swan should position itself in relation to circular economy. These included (1) setting requirements for incoming chemicals that increase the possibility of reuse and recycling, and (2) communicating the circularity of product life cycles better. ${ }^{107}$ Later, simultaneously with our report, the Nordic Swan Ecolabelling organisations have also prepared a broader view and a brochure about their role in promoting circular economy. ${ }^{108}$ This brochure describes that the "circular approach of the Swan" is based on six parameters:

- Requirements for renewable, recycled and sustainable raw materials.

- Strict chemical requirements.

- Reduced use of resources and energy.

- Quality requirements and life time.

- Requirements for product design, dismantling and reparability.

- Requirements for optimum waste handling.

Combining these principles of the "circular approach" and the "RPS" assessment process, the Swan can push towards continuous improvement and in a way that relevant requirements can be introduced during the periodic criteria revision process. The "RPS" aims to ensure that circular economy aspects that are relevant to the product group are included and that they are achievable. It also allows introducing new issues as they emerge.

The traceability and verifiability of the information provided by license applicants is crucial for the trustworthy functioning of the scheme. The ecolabel can, therefore, be a way for ensuring that claims by companies of addressing circular economy aspects are verifiable and justified (e.g., the use of secondary raw materials, reparability etc.).

${ }_{107}$ Nordic Swan Ecolabel (2014b).

108 Nordic Swan Ecolabel (2017a). 



\section{Conclusions and Recommendations}

The currently valid Nordic Swan Ecolabel criteria documents include requirements promoting the circulation of materials: recyclability, recycled content, and recycling both in the production and at the end-of-life. Recycling is required for all product groups in accordance with national product legislation. The possibility to separate materials is already seen in some criteria sets and is expected to gain strengthened attention in the future, as indicated by "New Criteria".

The Swan promotes the use of secondary raw materials in products and packaging by means of percentage requirements on recycled input or residues for some product groups. The "New Criteria" chapters indicate that in future criteria revisions, secondary raw materials will gain more importance. However, there are also limitations: there are product groups for which the use of recycled fibre seen is not possible today due to health or hygiene reasons.

The criteria documents include requirements promoting product service time extension through good quality products with requirements on durability, warranties and through requirements on the availability of replacement parts. However, more work could be done to understand whether the actual life time of a product with a Nordic Swan ecolabel is longer than that of a comparable non-labelled product.

We make the following recommendations to the Nordic Swan Ecolabel:

- Transfer good examples from product groups, where a circular approach is already well applied, to other product groups (e.g. remanufacturing).

- Strengthen requirements on the use of by-products, secondary components, multi-functionality, modularity, separability, repair and upgrade in setting new criteria.

- Assess the role of chemical-criteria in promoting non-toxic cycles.

We see that further research could be made on the following topics:

- What is the difference in durability and life-time of Nordic Swan ecolabelled products and comparable non-labelled products.

- The ways in which the Nordic Swan ecolabel could best use its steering role in pushing ecologically sound sharing economy service development. 
This report was prepared as part of a Nordic project, and the results could be useful in the development of the Nordic Swan Ecolabel in the future. The Swan criteria are revised every couple of years, which allows that consideration may be given to the results of this report in future criteria revisions. The Swan's strategy is on having fewer criteria, but set in a way that they are stringent on those that have the highest RPS outcome. SYKE agrees with this goal.

The Nordic Swan Ecolabel is a central tool that can steer consumer and producer choices through a market-based approach. Many decisions are taken in the product design phase and the criteria have the opportunity to influence and provide a benchmark to product developers and designers. The RPS approach could add value to the discussion on policies and market-based tools and the intervention role that they have in steering our economic system towards the circular economy. 


\section{References}

DIN standards website: http://www.din.de/en

Ellen MacArthur Foundation (2012). Towards the Circular Economy, Volume.

https://www.ellenmacarthurfoundation.org/publications/towards-the-circular-economy-vol-1an-economic-and-business-rationale-for-an-accelerated-transition

Ellen MacArthur Foundation (2015a). Material Circularity Indicators: An Approach to Measuring Circularity. Methodology. https://www.ellenmacarthurfoundation.org/programmes/ insight/circularity-indicators

Ellen MacArthur Foundation (2015b). Material Circularity Indicator Project Overview. https://www.ellenmacarthurfoundation.org/programmes/insight/circularity-indicators

European Commission (2008). Directive 2008/98/EC of the European Parliament and of the Council of 19th November 2008 on waste and repealing certain Directives.

http://eur-lex.europa.eu/legal-content/EN/TXT/?uri=celex\%3A32008Loog8

European Commission (2011). Communication from the Commission to the European Parliament, the Council, the European Economic and Social Committee and the Committee of the Regions:

Roadmap to a Resource Efficient Europe (Brussels 20.9.2011 COM(2011) 571 final). http://eur-lex.europa.eu/legal-content/EN/TXT/?uri=CELEX\%3A52011DC0571

European Commission (2015). Communication from the Commission to the European Parliament, the Council, the European Economic and Social Committee and the Committee of the Regions: Closing the loop - An EU Action Plan for the Circular Economy (Brussels 2.12.2015, COM(2015) 614 final. http://eur-lex.europa.eu/legalcontent/EN/TXT/PDF/?uri=CELEX:52015DCo614\&from=EN

European Commission (2015). Annex to the Communication from the Commission to the European Parliament, the Council, the European Economic and Social committee and the committee of the Regions: Closing the Loop - An EU Action Plan for the Circular Economy (Brussels 2.12.2015 COM82015) 614 final, Annex 1). http://eur-lex.europa.eu/legalcontent/EN/TXT/PDF/?uri=CELEX:52015DCo614\&from=EN

International Standards Organisation (ISO) (2006). Environmental Management. Life Cycle Assessment. Requirements and Guidelines - SFS-EN ISO 14044:2006.

International Standards Organisation (ISO) (1999). Environmental labels and declarations Type I environmental labelling - Principles and procedures - SFS-EN ISO 14024:1999.

Mäkivuokko, Karita (2001). Neuvonta materiaalitehokkuuden edistäjänä yrityksissätapaustutkimuksena materiaalitehokkuuden neuvontaohjelman arviointi. Suomen ympäristökeskus. Helsinki 2001/526.

Nordic Council of Ministers (2013). Nordic Environmental Action Plan 2013-2018. ANP 2012-766. Copenhagen. https://doi.org/10.6027/ANP2012-766

Nordic Swan Ecolabel (2014a). Goals and Principles for the Nordic Swan Ecolabel (the Swan). http://www.nordicecobel.org/CmsDocuments/About/Goals\%20and\%2oprinciples\%20Nordic\%2oEcolabel_O ct\%202014.pdf

Nordic Swan Ecolabel (2013a). Internt notat om RPS (RPS-guidanse) (internal document).

Nordic Swan Ecolabel (2013b). MEKA Vejledning for Nordisk Miljømærkning.

http://docplayer.dk/17727967-Meka-vejledning-for-nordisk-miljoemaerkning.html

Nordic Swan Ecolabel (2000). Miljöfilosofi (internal document).

Nordic Swan Ecolabel (2005). Miljøpionérer-arbeidet videre (internal document).

Nordic Swan Ecolabel (2014b). Notat om CradlezCradle og Cirkulær Økonomi (internal document). 
Nordic Swan Ecolabel (2016). Nordic Swan Ecolabelling Annual Report 2015. https://issuu.com/svanen123/docs/nordic_ecolabeling_annual_report_20

Nordic Swan Ecolabel (2011). Strategiske mål for Nordisk Miljömerkning 2012-2015 (internal document).

Nordic Swan Ecolabel (2017a). The Nordic Swan Ecolabel promotes circular economy (Brochure): https://joutsenmerkki.fi/teemat/kiertotalous/

Nordic Swan Ecolabel (2017b). Nordisk Miljömärkning, Utvärdering av Svanenmärkta engångsartiklar för mat, Version 3.3, 2016-02-17.

Nordic Swan Ecolabel Website: www.nordic-ecolabel.org

Nordic Swan Ecolabel Website, Finnish version: www.joutsenmerkki.fi

Nordic Swan Ecolabel (2011). Background to Nordic Swan Ecolabelling of Paper Products-basic module and chemical module, version 2.

Pommer, K. et al. (2001). Håndbog i miljøvurdering af produkter, Miljønyt nr. 582001. Miljøstyrelsen Danmark. http://www.mst.dk/Publikationer/Publikationer/2001/02/87-7944349-4.htm

Seppälä et al. (2016). Kiertotalous Suomessa - toimintaympäristö, ohjauskeinot ja mallinnetut vaikutukset vuoteen 2030. Valtioneuvoston selvitys-ja tutkimustoiminnan julkaisusarja 25/2016. http://vnk.fi/julkaisu?pubid=11902

Sitra (2014). Kiertotalouden mahdollisuudet Suomelle. Sitran selvityksiä 84. https://www.sitra.fi/julkaisut/kiertotalouden-mahdollisuudet-suomelle/

Swedish Society for Nature Conservation (SSNC). http://www.naturskyddsforeningen.se/inenglish/good-environmental-choice/textiles [August 2016].

UN (2017) Sustainable Development Goals: http://www.un.org/sustainabledevelopment/sustainable-consumption-production/ [June 2017].

University of Cambridge. Circular Economy Toolkit: http://circulareconomytoolkit.org/maintain-repair.html [June 2017].

Vigga Website. http://www.vigga.us/hvad-er-vigga/\#boernetoej [June 2017]

World Business Council for Sustainable Development (2017). Circular Economy Practitioners Guide. http://ceguide.org/Glossary [August 2017].

YouGov (2015). A Computer Assisted Web Interview Study in Norway, Sweden, Denmark, Finland and Iceland, commissioned by the Nordic Swan Ecolabel. Internal document.

\section{List of Nordic Swan Ecolabel Criteria}

Nordic Swan Ecolabel (2016) Nordic Swan Ecolabelling of Biofuel Pellets (Version 2.3, 13 December 2007- 31 March 2018).

Nordic Swan Ecolabel (2014). Nordic Swan Ecolabelling of Boilers for solid biofuel (Version 3.0, 11 June 2014 - 30 June 2019).

Nordic Swan Ecolabel (2015). Nordic Swan Ecolabelling of Candles (Version 1.4, 13 December 2007- 31 October 2016).

Nordic Swan Ecolabel (2015). Nordic Swan Ecolabelling of Car and boat care products (Version 5.6, 21 March 2012 - 31 December 2018).

Nordic Swan Ecolabel (2016). Nordic Swan Ecolabelling of Chemical building products (Version 2.5, 19 March 2014 - 31 March 2019).

Nordic Swan Ecolabel (2015). Nordic Swan Ecolabelling of Computers (Version 7.3, 23 October 2013 - 30 June 2019).

Nordic Swan Ecolabel (2014). Nordic Swan Ecolabelling of Compost Bins (Version 3.0, 11 June 2014 - 30 June 2019).

Nordic Swan Ecolabel (2016). Nordic Swan Ecolabelling of Cleaning agents for use in the food industry (Version 1.8, 13 October 2005 - 30 June 2018). 
Nordic Swan Ecolabel (2014). Nordic Swan Ecolabelling of Cleaning Products (Version 5.2, 13 March 2013-31 March 2017).

Nordic Swan Ecolabel (2014). Nordic Swan Ecolabelling of Closed Toilet Systems (Version 3.0, 11 June 2014 - 30 June 2019).

Nordic Swan Ecolabel (2016). Nordic Swan Ecolabelling of Construction and facade panels (Version 6.2, 25 February 2015 - 31 March 2020).

Nordic Swan Ecolabel (2015). Nordic Swan Ecolabelling of Copy and printing paper supplementary module (Version 4.2, 22 June 2011 - 30 June 2019).

Nordic Swan Ecolabel (2015). Nordic Swan Ecolabelling of Cosmetic Products (Version 2.11, 12 October 2010 - 30 June 2017).

Nordic Swan Ecolabel (2015). Nordic Swan Ecolabelling of De-icers (Version 2.5, 18 March 2004 - 31 December 2018).

Nordic Swan Ecolabel (2015). Nordic Swan Ecolabelling of detergents for professional use (Version 2.6, 21 June 2010-31 March 2018).

Nordic Swan Ecolabel (2016). Nordic Swan Ecolabelling of Dishwasher detergents and Rinsing agents (Version 6.3, 19 March 2014 - 31 March 2018).

Nordic Swan Ecolabel (2016). Nordic Swan Ecolabelling of Disposable bags, tubes and accessories for health care (Version 1.6, 13 December 2007 - 31 March 2019).

Nordic Swan Ecolabel (2016). Nordic Swan Ecolabelling of Disposables for Food (Version 3.4, 21 March 2012 - 31 December 2018).

Nordic Swan Ecolabel (2015). Nordic Swan Ecolabelling of Durable/resistant wood for outdoor use (Version 2.0, 25 February 2015 - 31 December 2019).

Nordic Swan Ecolabel (2014). Nordic Swan Ecolabelling of Floor Care Products (Version 4.3, 15 June 2012 - 30 June 2017).

Nordic Swan Ecolabel (2015). Nordic Swan Ecolabelling of Floor Coverings (Version 6.1, 18 November 2014 - 31 December 2019).

Nordic Swan Ecolabel (2015). Nordic Swan Ecolabelling of Fuel and biogas for heating and industrial use (Version 2.4, 15 June 2012 - 31 December 2017).

Nordic Swan Ecolabel (2015). Nordic Swan Ecolabelling of Furniture and Fitments (Version 4.11, 17 March 2011 - 30 June 2019).

Nordic Swan Ecolabel (2013). Nordic Swan Ecolabelling of Grease-proof paper (Version 4.0, 18 November 2014 - 31 December 2018).

Nordic Swan Ecolabel (2015). Nordic Swan Ecolabelling of Hand Dishwashing detergents (Version 5.3, 21 March 2012 - 31 December 2017).

Nordic Swan Ecolabel (2016). Nordic Swan Ecolabelling of Heat Pumps (Version 3.3, 13 March 2013 - 31 March 2019).

Nordic Swan Ecolabel (2013). Nordic Swan Ecolabelling of Imaging Equipment (Version 6.3, 20 June 2013- 31 December 2019).

Nordic Swan Ecolabel (2016) Nordic Swan Ecolabelling of Indoor paints and varnishes (Version 3.1, 5 November 2015 - 31 December 2019).

Nordic Swan Ecolabel (2016). Nordic Swan Ecolabelling of Industrial cleaning and degreasing agents (Version 3.0, 10 June 2015 - 30 June 2020).

Nordic Swan Ecolabel (2014). Nordic Swan Ecolabelling of Laundry detergents and stain removers (Version 7.7, 15 December 2011 - 31 December 2017).

Nordic Swan Ecolabel (2015). Nordic Swan Ecolabelling of Laundry detergents for professional use (Version 3.2, 19 March 2014 - 31 March 2019).

Nordic Swan Ecolabel (2016). Nordic Swan Ecolabelling of Machines for Parks and Gardens (Version 5.3, 13 March 2013-31 March 2019).

Nordic Swan Ecolabel (2015). Nordic Swan Ecolabelling of Office and Hobby Supplies (Version 4.2, 11 December 2013- 31 December 2018).

Nordic Swan Ecolabel (2016). Nordic Swan Ecolabelling of Outdoor furniture, outdoor fixtures and playground equipment (Version 3.8, 17 March 2011 - 31 March 2019). 
Nordic Swan Ecolabel (2013). Nordic Swan Ecolabelling of Paper Products-Basic Module (Version 2.1, 22 June 2011 - 30 June 2016).

Nordic Swan Ecolabel (2014). Paper Products - Chemical Module (Version 2.3, 22 June 2011 30 June 2016).

Nordic Swan Ecolabel (2015). Nordic Swan Ecolabelling of Primary Batteries (Version 4.5, 22 June 2011 - 30 June 2018).

Nordic Swan Ecolabel (2016). Nordic Swan Ecolabelling of Printing Companies, Printed matter, Envelopes and other Converted Paper Products (Version 5.10, 15 December 2011 31 December 2017).

Nordic Swan Ecolabel (2015). Nordic Swan Ecolabelling of Rechargeable Batteries (Version 4.5 7 December 2010 - 30 June 2018).

Nordic Swan Ecolabel (2016). Nordic Swan Ecolabelling of Remanufactured OEM Toner Cartridges (Version 5.2, 15 June 2012 - 30 June 2018).

Nordic Swan Ecolabel (2016). Nordic Swan Ecolabelling of Sanitary Products (Version 5.6, 5 March 2008 - 31 December 2017).

Nordic Swan Ecolabel (2016). Nordic Swan Ecolabelling of Small Houses, Apartment Buildings, Schools and Pre-schools (Version 3.0, 9 March 2016 - 31 March 2020).

Nordic Swan Ecolabel (2015). Nordic Swan Ecolabelling of Stoves (Version 4.1, 11 June 201430 June 2019).

Nordic Swan Ecolabel (2016). Nordic Swan Ecolabelling of Supplies for microfibre based cleaning (Version 2.3, 12 October 2010 - 31 March 2020).

Nordic Swan Ecolabel (2016). Nordic Swan Ecolabelling of Textiles, hides/skins and leather (Version 4.3, 12 December 2012 - 31 December 2018).

Nordic Swan Ecolabel (2016). Nordic Swan Ecolabelling of Tissue Paper (Version 5.5, 11 October 2011 - 31 December 2019.)

Nordic Swan Ecolabel (2015). Nordic Swan Ecolabelling of Toys (Version 2.2., 21 March 2012 31 March 2018).

Nordic Swan Ecolabel (2015). Nordic Swan Ecolabelling of TV and Projector (Version 5.4, 20 June 2013 - 30 June 2019).

Nordic Swan Ecolabel (2015). Nordic Swan Ecolabelling of White Goods (Version 5.1, 20 June 2013 - 30 June 2017).

Nordic Swan Ecolabel (2016). Nordic Swan Ecolabelling of Windows and Exterior Doors (Version 4.3, 19 March 2014 - 31 March 2018). 


\section{Sammanfattning}

Begreppet "cirkulär ekonomi" har uppstått de senaste åren som ett sätt att benämna en ekonomi där naturresurser används effektivt och deras värde bevaras i ekonomin så länge som möjligt. Den cirkulära ekonomin fokuserar väsentligen på två utmärkande egenskaper: produktens livstid och materialomsättning. För en övergång till cirkulär ekonomi krävs att medborgare och myndigheter har rätt verktyg för att välja produkter och tjänster med mindre miljöpåverkan, i form av lämpliga prissignaler och tillräcklig miljöinformation. Ett miljömärke visar att produkten ur miljösynpunkt tillhör de bästa produkterna som är tillgängliga på marknaden. Miljömärket Svanen har utformats för att stegvis styra utvecklingen mot hållbarhet. För denna rapport har specifika tilldelningskriterier för produktgrupper analyserats i syfte att identifiera krav som främjar en cirkulär ekonomi genom att förlänga produkters livstid och cirkulation av material.

Svanen främjar produkter av god kvalitet med krav på varaktighet genom garantier och tillgång till reservdelar. Användning av sekundära råvaror för produkter och förpackningar kan beaktas. Avskiljbarhet (möjligheten att avskilja material) beaktas redan som ett kriterium för vissa produktgrupper och förväntas få mer uppmärksamhet i framtiden, enligt vad som anges i avsnitten om "nya kriterier". Materialinnehållet är, i tillägg till avskiljbarhet, till hjälp eller hinder för återvinningsmöjligheterna. En viktig aspekt som noteras $\mathrm{i}$ analysen är förekomsten av skadliga kemikalier, som kan förhindra återvinning. Sådana kemikalier är begränsade av miljömärkningskrav.

Denna rapport har skrivits som en del av ett projekt finansierat av Nordiska Ministerrådet och resultaten kan vara användbara för framtida utveckling av det nordiska miljömärket. Framtida utveckling av kriterier skulle kunna fokusera mer på aspekter som inkluderar möjligheten att uppgradera och reparera produkter, liksom ökad återanvändning av komponenter. För det andra, så rekommenderas att miljömärkets roll $i$ att främja innovativa former av konsumtion och tillverkning, till exempel delningsekonomi, och som omfattas av cirkulär ekonomi bör utvecklas, och att den tillhörande processen som används för att fastställa kriterierna bör utvärderas. Det nordiska miljömärket Svanen är ett centralt verktyg med vilket man kan styra konsumtions- och produktionsval utifrån en marknadsbaserad ansats. 
Nordic Council of Ministers

Nordens Hus

Ved Stranden 18

DK-1061 Copenhagen $\mathrm{K}$

www.norden.org

\section{CIRCULAR ECONOMY AND THE NORDIC SWAN ECOLABEL}

The transition to Circular Economy necessitates right incentives for choosing products and services with lower environmental impacts, in the form of price signals and sufficient environmental information. An ecolabel indicates that the product is, environmentally speaking, among the best products available on the market and thus has the role to steer stepwise developments towards sustainability. The Swan criteria promote quality products with requirements on durability and the use of secondary raw materials. To further align the criteria with Circular Economy, future criteria development might focus more on aspects including upgradability, reparability, multi-functionality, component reuse and innovative forms of consumption and production. This report was prepared as part of a Nordic project, and the results could be useful in the development of the Nordic Ecolabel in the future. 